San Jose State University

SJSU ScholarWorks

Master's Theses

Master's Theses and Graduate Research

Fall 2017

\title{
Traditional Ecological Knowledge in Collaborative Forest Restoration in the Sierra Nevada
}

Michael Boero

San Jose State University

Follow this and additional works at: https://scholarworks.sjsu.edu/etd_theses

\section{Recommended Citation}

Boero, Michael, "Traditional Ecological Knowledge in Collaborative Forest Restoration in the Sierra Nevada" (2017). Master's Theses. 4868.

DOI: https://doi.org/10.31979/etd.3es8-b2k7

https://scholarworks.sjsu.edu/etd_theses/4868

This Thesis is brought to you for free and open access by the Master's Theses and Graduate Research at SJSU ScholarWorks. It has been accepted for inclusion in Master's Theses by an authorized administrator of SJSU ScholarWorks. For more information, please contact scholarworks@sjsu.edu. 


\title{
TRADITIONAL ECOLOGICAL KNOWLEDGE AND COLLABORATIVE FOREST RESTORATION IN THE SIERRA NEVADA
}

\author{
A Thesis \\ Presented to \\ The Faculty of the Department of Anthropology \\ San José State University \\ In Partial Fulfillment \\ Of the Requirements for the Degree \\ Master of Arts
}

By

Michael Boero

December 2017 
(C) 2017

Michael Boero

ALL RIGHTS RESERVED 
The Designated Thesis Committee Approves the Thesis Titled

TRADITIONAL ECOLOGICAL KNOWLEDGE AND COLLABORATIVE FOREST RESTORATION IN THE SIERRA NEVADA

by

Michael Boero

APPROVED FOR THE DEPARTMENT OF ANTHROPOLOGY

SAN JOSÉ STATE UNIVERSITY

December 2017
Dr. Charlotte Sunseri
Department of Anthropology
Dr. A.J. Faas
Department of Anthropology
Dr. Ana Pitchon
Department of Anthropology 


\section{ABSTRACT \\ TRADITIONAL ECOLOGICAL KNOWLEDGE AND COLLABORATIVE FOREST RESTORATION IN THE SIERRA NEVADA \\ By Michael Boero}

Forest restoration in the Sierra Nevada is receiving increased attention due to climate change, increasing populations in the wildland-urban interface, and the historical mismanagement of some forests, evidenced in part by the increasing frequency and severity of wildfires in recent years. In response to an urgency to implement restoration in the absence of consensus on the best ways to proceed, public land managers practice collaborative management approaches to ameliorate antagonism between stakeholders and allow restoration projects to proceed when agreement is difficult to achieve. Stakeholders often include representatives from local community groups, environmental organizations, private industry, and—notably—-tribal groups, who hold traditional ecological knowledge recognized as valuable for informing land management perspectives, methods, and assessment. In response to apparent ambiguities surrounding the theoretical and practical dynamics of tribal collaboration within forest restoration projects, my study employs an ethnographic approach to identify the complexities that occur between local tribal communities and the United States Forest Service within one CFLRP project: The Dinkey Collaborative, located in California’s Sierra Nevada. Through participant observation and in-depth interviews within the collaborative, I present parallel and divergent conceptualizations of the collaborative process among tribal and agency participants. 


\section{ACKNOWLEDGEMENTS}

First, I must acknowledge and thank Ron Goode for sharing his knowledge, passion, and homeland with me. Without him, this project would not be possible. Special thanks are also owed to my thesis committee. To Dr. Charlotte Sunseri, whose positivity and insight has inspired me ever since I stumbled into her archaeological field school in 2012.

To Dr. A.J. Faas, thanks are due for his steady and enthusiastic encouragement of my work and for always being accessible. To Dr. Ana Pitchon, for joining my committee and providing a wealth of knowledge in an area I am only beginning to grasp. And finally, I owe an immense amount of gratitude to my friends and family_-for joining me on long trips to the mountains and for always stoking my curiosity. Especially, though, I must thank my parents for their unwavering support and love. And to my Dad specifically, who taught me that even procrastination is an art that ought to be perfected. 


\section{TABLE OF CONTENTS}

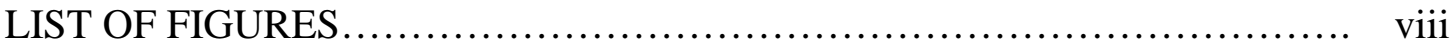

LIST OF ABBREVIATIONS .............................................. ix

CHAPTER 1: INTRODUCTION............................................ 1

Project Objectives...................................................... 4

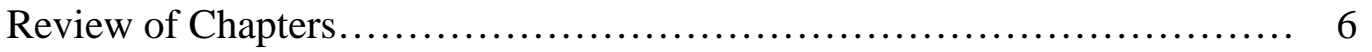

CHAPTER 2: ADAPTIVE MANAGEMENT AND COLLABORATION IN

NATIONAL FOREST MANAGEMENT ..................................... 8

The Collaborative Forest Landscape Restoration Program.................... 9

The Dinkey Landscape.................................................... 11

The Dinkey Collaborative............................................ 11

CHAPTER 3: THE UNITED STATES FOREST SERVICE AND AMERICAN

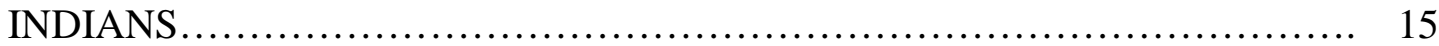

Indian Tribes of the Sierra Nevada................................... 16

Tribal Collaboration on the Sierra National Forest............................ 18

A Changing Landscape............................................... 21

The Dinkey Landscape Restoration Strategy............................ 22

CHAPTER 4: APPROACHES TO HISTORICAL AND TRADITIONAL

ECOLOGIES.............................................................. 25

Historical Ecology ............................................... $\quad 25$

Anthropology, Archaeology, and Indigenous Ecological Management......... 27

Traditional Ecological Knowledge in Land Management...................... 29

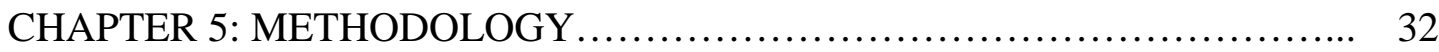

Project Objectives............................................... 32

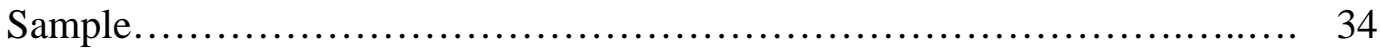

Participation in Meadow Restoration Projects............................. 36

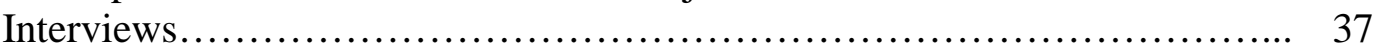

Data Collection and Analysis....................................... 38

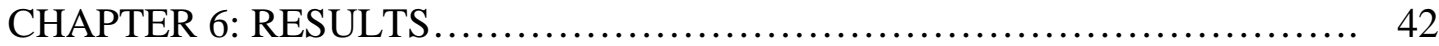

Collaborative Implementation......................................... 43

Ecological Rationale, Methods, and Outcomes............................ 47

Restoration in Practice................................................ 53

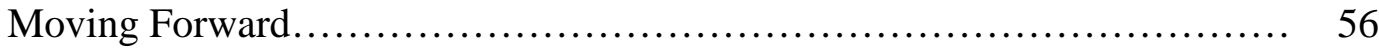

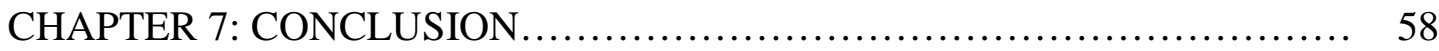

Future Research Directions.......................................... 62 
REFERENCES.................................................. 64

APPENDIX A: CONSENT FORM..................................... 72

APPENDIX B: INTERVIEW QUESTIONS............................ 74

APPENDIX C: INTERVIEW WITH NORTH FORK TRIBAL CHAIRMAN

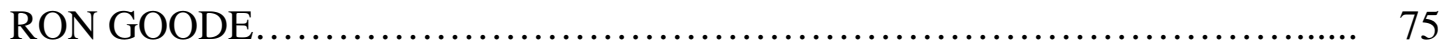




\section{LIST OF FIGURES}

Figure 1 - Map of the Dinkey Collaborative landscape....................... 12

Figure 2 - Map of the Sierra National Forest vicinity......................... 18

Figure 3. Crane Valley Meadow, Sierra National Forest........................ 39 


\section{LIST OF ABBREVIATIONS}

CFLRP - The Collaborative Forest Landscape Restoration Program

NFM - The North Fork Mono Tribe

SNF - Sierra National Forest

TEK - Traditional ecological knowledge

USDA - United States Department of Agriculture

USFS - United States Forest Service 


\section{Chapter 1: Introduction}

The purpose of this study is to highlight the complexities that occur between tribal and agency participants in collaborative forest restoration in the Sierra Nevada of California. An annual wildfire season that endangers lives and property has become the norm in California and other western states. Wildfires are occurring with greater severity, adversely affecting ecosystems and communities living in wildfire prone areas while increasing state and federal fire suppression costs. Wildfires cause substantial economic disruptions, owing to the destruction of infrastructure, degradation of ecosystems, loss of life, and smoke-related health effects. Unfortunately, wildfires are getting worse at a rapid rate: global climate change is already increasing the frequency of mega-fires and growing populations will lead to increased ignition risk regardless of climate change (Mann et al. 2016; Miller et al. 2009; Running 2006). Accordingly, the cost of fighting wildfires is also rising dramatically (Michel 2014). The United States Forest Service (USFS) alone spent \$1.2 billion annually between 2001 and 2010 on fire suppressionnearly double the annual amount spent during the previous decade. Between 1993 and 2002, an average of about 4 million acres burned in the U.S. every year. By 2012, that number nearly doubled to over 7 million acres (Michel 2014:27). Furthermore, at least 39 percent of U.S. housing units are now located within, or in proximity to, wildfire-prone areas — called the wildland-urban interface (WUI) — with 5.1 million homes in California alone (Radeloff et al. 2005). Increasing human encroachment into the WUI will only increase ignition risks and, combined with climate change, the threat of more destructive fires in the future is inevitable. 
It should be said, though, that many environmental factors combine to dictate the severity of a given fire season, including annual precipitation, wind conditions, and lightning strike occurrence (Carle 2008). These variables make it difficult to say concretely how frequent or severe wildfires will continue to become. However, what we can conclude is that human-initiated influences will inevitably continue to increase ignition risk and fire severity over the next few decades (Syphard et al. 2007). While population growth and climate change play key roles in creating the kinds of environments that foster dangerous fire conditions, the historical (mis)management of many public forests and grasslands also plays a determining role. Unintended consequences of twentieth century fire exclusion, characterized by aggressive suppression tactics, have caused fuel loads (i.e. vegetation and other combustible materials) to build up to such a degree that forests and other wildlands are increasingly vulnerable to large, catastrophic wildfires (Carle 2008). For most forests in the American West, a paucity of low-intensity, periodic fires results in an ecologically detrimental overcrowding of trees and underbrush. This leaves forested landscapes more susceptible to the devastating, high-severity wildfires so common in California and other Western states, inevitably putting more people and ecosystems at risk.

A delicate line exists between climate change and Sierra Nevada forests. Especially during periods of prolonged drought, the relationship cannot be understated. For instance, per a 2005 California State Department of Water Resources report, the Sierra Nevada receives 27 percent of California's annual precipitation and provides more than 60 percent of the state's consumptive use of water (Bales et al. 2011). Consequently, the 
Sierra Nevada canopy cover — the proportion of the forest floor covered by the vertical projection of the tree crowns—should be reduced by 40 percent to ensure adequate runoff and infiltration of water into streams and aquifers (Bales et al. 2011). While today's dense Sierra Nevada woodlands provide less runoff than historical forests, a University of California forest study (Downing 2015) suggests strategic tree thinning could add up to 16 percent more to the annual water flow out of the Sierra Nevada and into California's water supply. Currently, though, the Sierra's canopy cover is 80 percent to 90 percent closed. To provide some historical context, prior to 1850, before mass settlement, the average Sierra Nevada forest canopy was closed at a 40 percent rate. And while some more progressive forest districts are attempting to drop that proportion to 60 percent, forest managers often encounter resistance from groups who oppose this approach.

Adding further complexity to this articulation between California forests and climate change, an overcrowding of trees and a lack of water also exacerbate the damage caused by bark beetles, owing to 50-60 percent tree mortality in many areas of the Sierra Nevada in the past few years (Hernandez 2015). In November 2016, for example, the United States Department of Agriculture (USDA) announced that an additional 36 million trees had died across California since its last aerial survey only six months earlier (Hernandez 2015). This brought the total number of dead trees across the state since 2010 to over 102 million across 7.7 million acres of parched forest. In 2016 alone, an estimated 62 million trees died, representing a more than 100 percent increase in dead trees across the state from 2015. Five consecutive years of severe drought in California, a dramatic rise in bark beetle infestation, and warmer temperatures are leading causes of these historic levels of 
tree mortality. The same management actions that result in dense forests are not only blamed for an increase in catastrophic wildfire activity, but also for exacerbating devastating tree mortality. Over-suppression of wildfires and the inability to thin overcrowded forests has reduced the Sierra Nevada's ability to withstand long periods of drought like the one observed in recent years. The issue at hand is not that scientists and land management agencies do not recognize the essential problem, but that restoration treatments are likely hindered by social, political, and economic variables at multiple scales (Charnley et al. 2015).

Since the 1980s and 1990s, public land managers’ efforts to take preventive measures in the face of restoration needs has been to deploy adaptive management approaches that encourage collaboration among various stakeholders in the planning process of projects. Tribal groups are influential stakeholders within public land management projects on USFS lands because of the deep knowledge they hold about many different landscapes, but also because of the special government-to-government relationship that tribes hold with federal land management agencies like the USFS. In this thesis, I examine the complexities of one collaborative project involving tribal and agency participants in response to apparent ambiguities. Through participant observation and in-depth interviews, I unpack the tensions surrounding the theoretical and practical dynamics of collaboration within the Dinkey Collaborative.

\section{Project Objectives}

The Dinkey Collaborative offers an opportunity to explore multiple questions relating to the practice and theory of collaborative implementation involving tribal stakeholders in 
public lands management. First, the study aims to determine how tribal and agency participants conceptualize restoration in practice. This objective fills a knowledge gap by exploring how tribal and agency participants conceptualize collaborative implementation in comparison to the intentions of collaborative forest restoration policy. Secondly, I seek to discover how tribal and agency participants conceptualize the rationale, method, and ecological outcome of restoration efforts. By identifying diverse conceptualizations, areas of agreement can be established to foster more effective partnerships that enhance mutual goals of cultural and natural resource vitality. Thirdly, I am interested in how tribal and agency participants conceptualize collaborative implementation in practice. Collaborative implementation involves navigating new opportunities for stakeholder participation in forest management processes and requires a discussion of how this kind of collaboration deviates from typical project procedures.

Finally, I hope to contribute to the restoration, maintenance, and enhancement of natural resources important to Native American cultures, local communities, and all Californians who rely on the vital ecosystem services provided by Sierra Nevada forests. Studies like this should aim to benefit multiple stakeholders, including tribal groups, whose cultures are threatened in part because of the obstacles they often face in continuing traditional practices, including a lack of access to and the degradation of plant quality on public lands. For public land managers, the results detailed here address current landscape management issues in the U.S. such as the richness and diversity of native species, landscape productivity and heterogeneity, and mitigating fire and drought risk. Ultimately, though, I intend to make connections between indigenous land tenure, 
sovereignty, and descendant communities in the Sierra Nevada towards a more holistic view of the problem at hand.

\section{Review of Chapters}

The following chapters follow a logical progression by first summarizing adaptive resource management approaches in U.S. forest management-not only why public land managers would employ an adaptive management approach, but also how this approach is manifest in federal policies like the Collaborative Forest Landscape Restoration Program (CFLRP). Then, for the sake of this report, I also detail the CFLRP project that is depicted here: The Dinkey Collaborative.

The approach of land managers today is to collaborate and in the next chapter I explicate what this collaborative turn in forest management means for American Indian tribes. It begins with a broad summary of the political articulation between the USFS and American Indian tribes in the U.S., followed by a brief overview of tribal groups in the Sierra Nevada, past and present. Important here is a consideration for the staggering changes to Sierra Nevada landscapes brought on by Euro-American colonists. The focus then shifts back to the Dinkey Collaborative, paying close attention to its restoration strategy and drawing out the stated goals of the project.

The conceptual frameworks supporting this study's major inquiries are discussed next. The third chapter juxtaposes Western and non-Western approaches to ecological management in the context of Sierra Nevada forests. In it, I first describe the historical ecological models that drive contemporary approaches to land management followed by a brief exploration into the state of anthropological and archaeological research on pre- 
Columbian indigenous resource management in the Sierra Nevada. Particularly, I pay close attention to how this historical ecological data is important for informing contemporary forest management. I supplement this perspective with a discussion of traditional ecological knowledge, how it articulates with scientific ecological knowledge, and why it matters for contemporary forest management.

After that essential framework, I explain the methodological devices, procedures, and phases employed in this study. I expound on the project objectives and research questions, introduce my sampling strategy, data collection instruments, and procedures and include a project timeline, describing the data collection and analysis that took place in the study. The research arrived at a handful of meaningful results that isolate points of both tension and overlap among tribal and agency participants and I pay close attention to their consequences for tribal collaboration in general. The major issues presented here remain grounded in the overall research questions, leading to a conclusion that extrapolates the results toward broader contexts. 


\section{Chapter 2: Adaptive Management and Collaboration in National Forest Management}

The approach of land managers today is to collaborate with multiple resource specialists and stakeholders in project planning to not only refine management decisions, but to bolster stakeholder consensus over the best ways to manage public lands (Scarlett 2013). Beginning in the 1980s and 1990s, in response to an urgent need for refined forest management and to ameliorate antagonism between groups unable to reach consensus on the best ways to proceed, government land managers adopted adaptive land management as a potential normative framework to overcome "analysis paralysis" and allow management to proceed even when uncertainties remain (Butler et al. 2015). Adaptive management utilizes an experimental approach while actions are undertaken on the landscape followed by monitoring to determine whether the strategy was effective or not. This creates a sort of feedback loop, allowing uncertainties to be redressed over time and management to proceed based on the best available information. Considering the urgency to restore numerous and various landscapes in the U.S., adaptive management offers an effective way for land managers to proceed despite uncertainties.

A major principle of adaptive management is social learning through collaboration with diverse stakeholders to inform both current and future management decisions (Lee 2001). Collaboration in this context is defined as "an approach to solving complex environmental problems in which a diverse group of autonomous stakeholders deliberate to build consensus and develop networks for translating consensus into results” (Margerum 2011:6). A consensus can range from a simple majority to unanimous agreement among stakeholders regarding a decision. Often, though, it simply means 
reaching a decision that everyone can live with. The more complete the consensus, the more likely stakeholders will support implementation of the decision that is reached (Margerum 2011). Therefore, a focus on collaboration is paramount towards informing management decisions.

Collaboration in national forest management often occurs through community-based collaborative groups. These groups consist of local stakeholders coming together at the community scale to address natural resource management issues that affect the environmental or economic health of the community (Firehock 2011). They are usually composed of a diverse group of local stakeholders who make decisions and recommendations to influence the management of public lands and resources and take actions to implement them. These collaboratives are, by design, intended to prevent delay caused by a lack of consensus and subsequently prevent litigation that can often stall project implementation. This collaborative turn in forest management has resulted in the creation of policy and legal frameworks that encourage adaptive co-management in federal land management projects. I discuss one of these initiatives below.

\section{The Collaborative Forest Landscape Restoration Program}

When President Barack Obama and the U.S. Congress passed the Forest Landscape Restoration Act in 2009, they established the Collaborative Forest Landscape Restoration Program (CFLRP). The CFLRP officially encourages landscape scale restoration on National Forest System lands managed by the USFS. Generally, it is in response to the more than 65 million acres of National Forest lands that need restoration treatment via mechanical thinning and prescribed burning (Bixler and Kittler 2015). The Government 
Accountability Office recently echoed a similar sentiment: that to address large-scale impacts of wildfire, climate change, and other ecological stressors, forest restoration should be "undertaken at a scale commensurate with the scale at which disturbances...are occurring” (GAO 2015). Increasing the size and quantity of restoration projects on National Forests has become a top priority for the USFS and collaboration has become a primary tool for achieving project objectives (Bixler and Kittler 2015; Butler et al. 2015; Schultz et al. 2012).

In the CFLRP, projects must aim to reduce wildland fire management costs, enhance ecological health, and promote the economic use of restoration byproducts. Also, they are obligated to engage in collaboration with multiple stakeholders throughout project planning, implementation, and monitoring. The policy is important because of its innovative turn in forest management policy due to a focus on landscape scale restoration and requirements for collaboration in all phases of implementing the law (Schultz et al. 2012). Compared with previous collaborative efforts that occurred primarily during the planning stage—with implementation and monitoring carried out almost exclusively by the relevant agency—the CFLRP requires implementation and monitoring to be undertaken collaboratively, as well. Some, however, (Butler et al. 2015) have described how collaborative implementation of restoration presents challenges for public land managers who idly adhere to systems of authority, accountability, and legitimacy laid out in agency guidelines and procedures that are inherently incommensurate with the collaborative process. Similarly, restoration projects intended to reduce wildfire risk are hindered by various social, political, and economic factors (Charnley et al 2015). Further, 
they argue, agency history and culture have shaped professional identity and practices for more than a century, suggesting that—despite policy requirements—a tension that public land managers must negotiate is not only how much they can collaborate, but how much they are willing to do so (Butler et al. 2015).

\section{The Dinkey Landscape}

The CFLRP establishes a competitive funding program that solicits proposals from existing forest collaborative groups for landscape scale restoration programs. This report focuses on The Dinkey Collaborative, one group of stakeholders and agencies awarded funds by the CFLRP for restoration of an area in the central Sierra Nevada referred to as the Dinkey Landscape (Figure 1). The project area covers 154,000 acres of the Sierra National Forest (SNF) and private lands in California's Sierra Nevada. The project includes 130,000 acres of National Forest land and 24,000 acres of private land, with 20,000 acres of that private land owned by established landscape partners. The project landscape is in an area host to a long history of conflict and litigation over project impacts, particularly on threatened wildlife species. For instance, during previous projects in the area, stakeholders often cited conflicting studies to justify their proposed management recommendations (Bartlett 2012:83). As a result, the Forest was "paralyzed by science.” Efforts by local land managers to improve these relations were parlayed into a CFLRP proposal.

\section{The Dinkey Collaborative}

In 2010, the Dinkey Collaborative was granted $\$ 10$ million in funding over ten years, seeking to accelerate restoration treatments on both federal and private lands. The 
targeted landscape encompasses three broad vegetation types that are prioritized ecosystems within the Sierra Nevada bioregion: (1) coniferous forest, (2) foothill hardwood and chaparral vegetation, and (3) montane meadows and riparian forests. A key feature of the project is collaboration among diverse stakeholders (tribal,

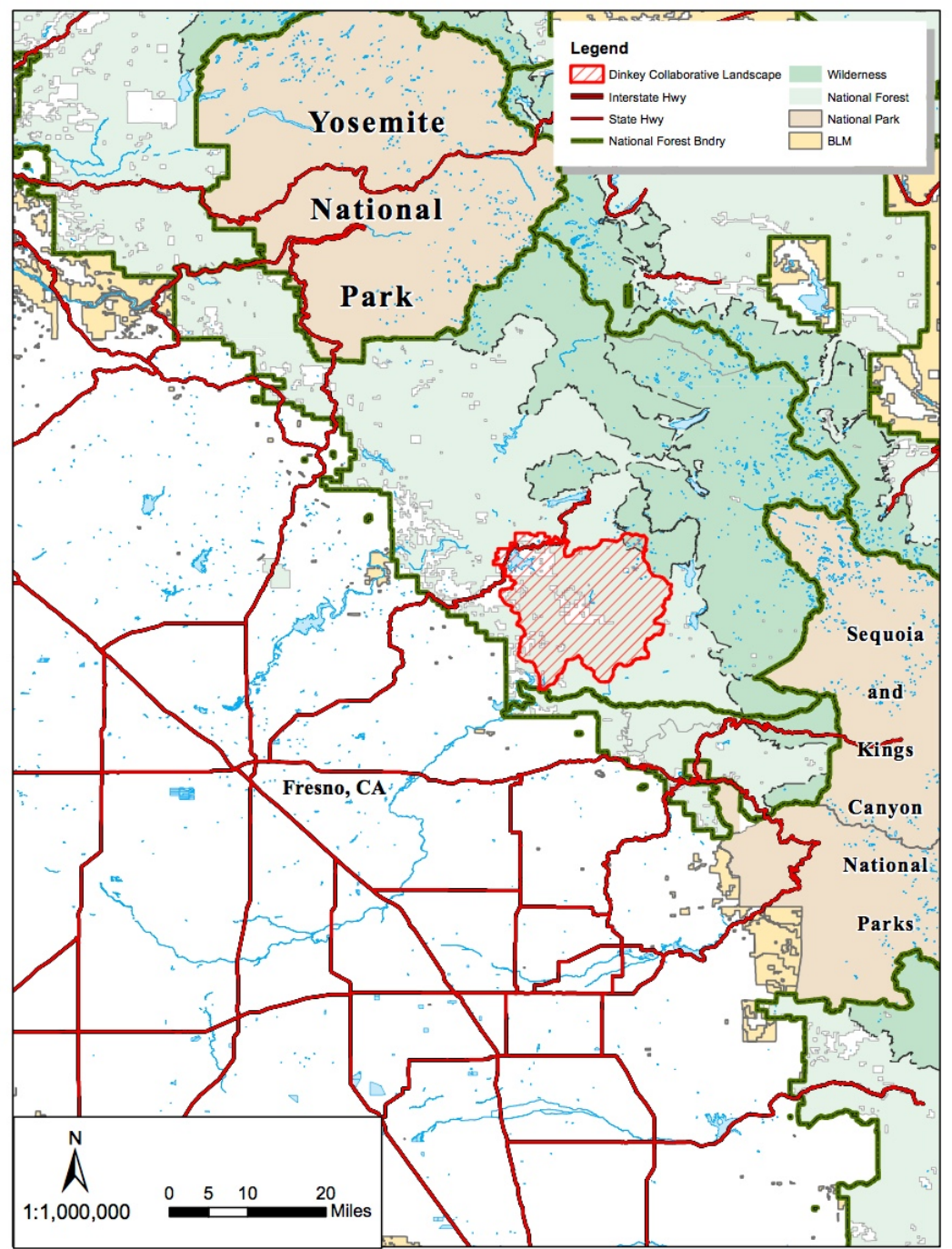

Figure 1. The Dinkey Collaborative landscape 
environmental, extractive industry, private land owners, federal, state, and others), guided by a science-based strategy towards ecological restoration. This study focuses on how tribal stakeholders' ecological knowledge and management perspectives articulate within the collaborative process, particularly in the implementation phase of landscape scale restoration efforts. 


\section{Chapter 3: The United States Forest Service and American Indians}

Boasting 818 million acres of forested land, the U.S. is the fourth-most forested country in the world. These forests are responsible for holding more than half the country's water supply and absorbing 12 percent of its carbon emissions (USDA Forest Service 2014). The USFS, administered by the USDA, is responsible for the sustainable stewardship of 18 million acres of forest lands on Indian reservations, 68 million acres of state forest land, more than 137 million acres of urban and community forests, and 423 million acres of private forest land, in addition to the 193 million acres of land it manages as part of the National Forest System. These National Forest System lands include 154 national forests, 20 national grasslands, and 1 national tallgrass prairie and cover 43 states, Puerto Rico, and the U.S. Virgin Islands (USDA Forest Service 2016).

According to 2010 Census data, the population of American Indians and Alaska Natives is a combined 5.2 million. Many distinct indigenous groups make up 567 federally recognized tribal nations, existing as sovereign governments in 34 states. Since the arrival of European colonists and the formation of the U.S., tribal governments have lost as much as 98 percent of their precontact land base (Smith 2004). In addition to the 18 million acres of forested land on Indian reservations, roughly 52 million acres of land are held in trust by the U.S. for various Indian tribes and individuals. While much of the lands administered by the USFS and other federal agencies were ceded to the U.S. by tribes, and while they no longer reside on those lands, many tribes retain rights and interests in national forests and grasslands via treaty. Of all the acres held in trust for tribes, nearly 4,000 miles border USFS lands. Notably, federally recognized tribes hold a 
government-to-government relationship with the U.S., set forth in the Constitution, treaties, statutes, court decisions, Executive orders, and Presidential memoranda. From 1778 to 1871 , for instance, the U.S. government ratified approximately 400 treaties with Indian nations, agreeing to preserve their ability to exercise their sovereign rights as they were reserved by the signatory tribes. In the following section, I detail the tribes of the Sierra Nevada in California, paying close attention to their past and present.

\section{Indian Tribes of the Sierra Nevada}

There were numerous, distinctive cultures in the Sierra Nevada at the time of historic contact. During the early 1800s, the region was inhabited by approximately thirteen “tribes” (ethnic groups speaking separate languages) composed of many “tribelets” (Kroeber 1962). This variety of cultures was reflected in diverse adaptations to Sierran environments and myriad land-use and resource management strategies. Tribes on the west side of the Sierra included the Maidu, Konkow, Nisenan, Northern Sierra Miwok, Central Sierra Miwok, Southern Sierra Miwok, Foothill Yokuts, Western Mono, and Tübatulabal. On the east side of the mountains were the Northern Paiute, Washoe, and Owens Valley Paiute. The Kawaiisu held land on both sides of the range. Occupying higher elevations of the central and southern Sierra Nevada were the Western Mono (Monache), with six geographic subdivisions: The North Fork Mono, Wobonuch, Entimbich, Michahay, Waksachi, and Patwisha (Spier 1978).

Although today their ancestral lands are occupied mostly by other peoples, each Native American community in the Sierra Nevada has maintained a distinct ethnic identity. Their contemporary needs, goals, and worldviews have stemmed from a difficult 
past, including 200 years of Indian resistance to the Euro-American appropriation of land and resources (Cook 1976; Heizer 1974; Phillips 1993; Rawls 1984). Many native groups today regulate their business and financial affairs through formal tribal councils. Intraand inter-tribal gatherings occur up and down the Sierra Nevada annually and are known variously as acorn festivals, Indian days, big times, and powwows. Many current Native American cultural activities have emerged from a combination of ancient botanical knowledge and a continued interest in their cultural heritage (Anderson and Moratto 1996). Many languages in the Sierra Nevada are still spoken, but some of the cultural groups only have one or two fluent speakers left (Hinton 1994). Individuals of all ages and both sexes still gather plants. Most tribes in the Sierra Nevada hold an insignificant land base or none at all and, consequently, are forced to gather mostly on public lands. The loss of habitat for culturally significant plants is extensive.

Despite a turbulent history and subsequent acculturation, California Indian elders are still a substantial source of information about present and former traditional plant uses and management practices, and in some cases, are still practicing plant management. Burning for cultural resources occurred surreptitiously on USFS lands until the 1950s, and some traditional management is still conducted on several reservations and rancherias. Unfortunately, many plant ecologists and resource managers still distrust or discount what they may view as merely anecdotal information. Yet, some of the richest details of former resource management practices have come from ethnographic interviews conducted in the past couple of decades (Anderson 1999; 2005). The validity of these accounts is verified through cross-referencing evidence from other families, both 
within and between tribes. Oral histories are then united with information from museum studies, ethnographic and ethnohistorical accounts, and the archaeological record to provide the most comprehensive reconstruction of past human actions on the land. Native American systems of knowledge about the environment have a great deal to teach resource managers. For instance, some tribal groups have been involved in blending Western and non-Western knowledge systems in on-the-ground resource management on USFS lands (Anderson 1992; 2005; Richards and Creasy 1996).

\section{Tribal Collaboration on the Sierra National Forest}

The SNF, situated on the western slopes of the Sierra Nevada, encompasses more than 1.3 million acres of federally-owned public land (Figure 2). Elevations range from 900 feet in the west to nearly 14,000 at the Sierra crest to the east. Like many Sierra Nevada forests, meadows serve an important role in ecosystem function on the SNF, essentially acting as sponges through which precipitation flows into vital aquifers. Also, for Native American groups such as the North Fork Mono (NFM), whose ancestral territory is subsumed by much of the SNF. they serve important cultural functions, providing vital plant and animal resources and traditional gathering areas. Following this reasoning, collaborative restoration projects involving the tribe typically show an emphasis on meadows. Many meadows in the SNF are important gathering areas for the NFM, and documented village sites surrounding some of these meadows punctuate a deep historical relationship between indigenous peoples and the land. However, the NFM tribe has suffered from a lack of access to these traditional gathering areas and the degradation of plant quality. Starting in 2001, though, the tribe entered a partnership with 


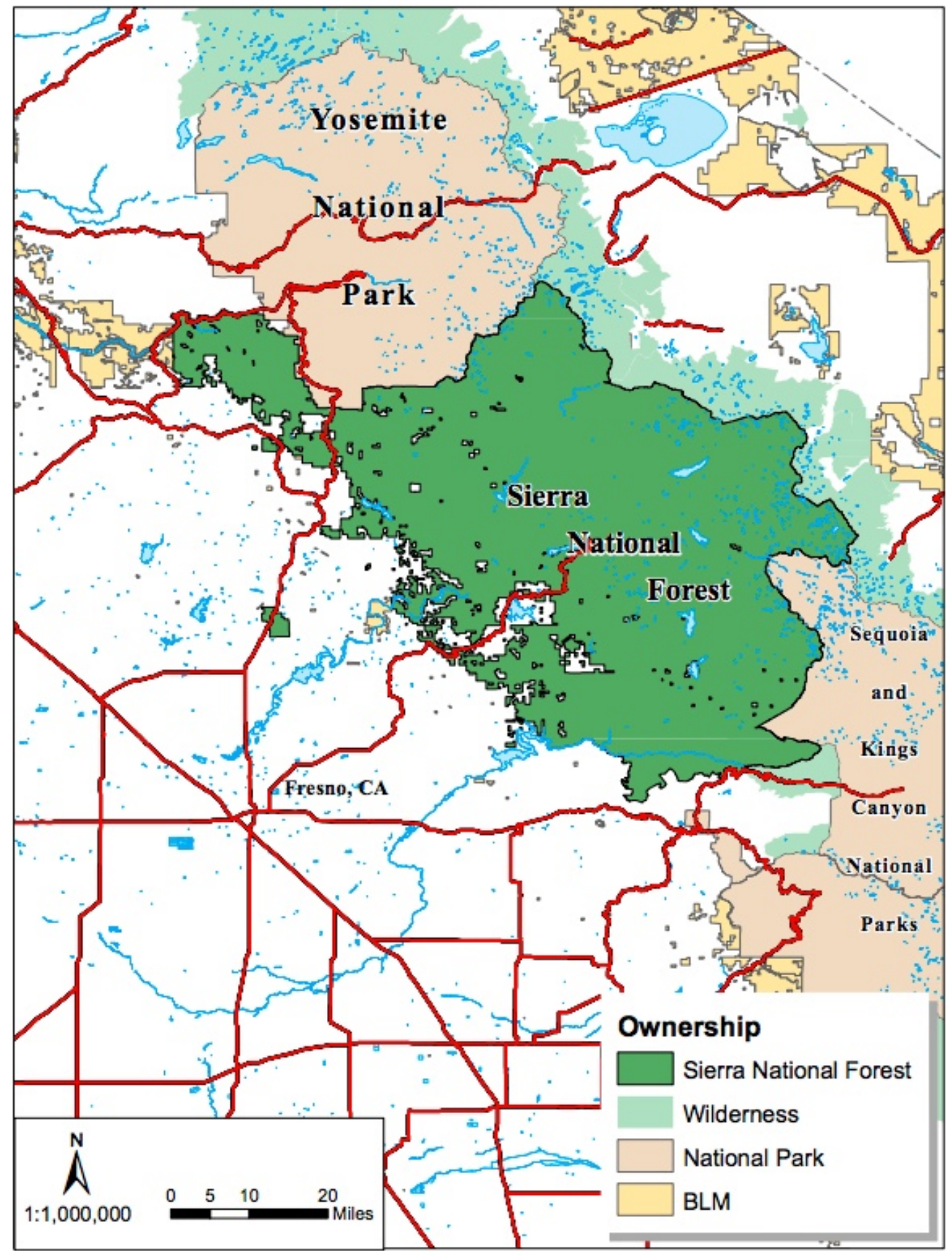

Figure 2. Map of the Sierra National Forest vicinity 
the USFS to manage culturally significant plant resources on selected meadows through selective tree removal and cultural burning (i.e. prescribed fire). In the fifteen years since the tribe was awarded this opportunity, many of the meadows have seen increased biodiversity, water retention, and wildfire risk reduction.

While ecological restoration goals may be in harmony in the outset of these partnerships, it is not uncommon for tribal perspectives to be in discord with environmental groups and agency land managers. This is not to say that traditional perspectives are not acknowledged by land management agencies. Land managers are increasingly acknowledging the legitimacy and utility of traditional ecological knowledge, as well as a recognition of the ecological impacts of indigenous resource management on pre-Colombian landscapes. This recognition is certainly not new to anthropologists, archaeologists, and environmental historians who argue that before the arrival of Europeans, Native Americans employed a variety of land management techniques which made significant impacts on the "American wilderness" found by these early explorers and settlers (Vale 2002). California was not exceptional in this regard, as Native Californians set fires across the state, from coastal forests and grasslands to inland oak savannas and montane meadows, shaping many of the Golden State's signature ecosystems and plant communities (Anderson 2005). Through proto-agricultural management techniques, especially the intentional setting of fires, Native Californians added considerable degrees of predictability to adaptations that depended upon a range of habitats at various stages of ecological succession. This is in contrast with a false conception of Native Californians that anthropologists and historical ecologists have done 
well to mostly shed over the last thirty years. In the Sierra Nevada, especially, the benefits of strategically applied human-initiated fire allowed Native Californians to free themselves from a dependence on random and unpredictable occurrences of lightning fires, strategically removing the fuel loads that today often cause catastrophe.

\section{A Changing Landscape}

With the arrival of Spanish missionaries in the eighteenth century, and the subsequent invasion of miners, farmers, ranchers, and other settlers in the nineteenth century, Native American fire regimes were effectively discontinued in response to colonial regulations and because of genocidal population loss. This loss of Native American ignitions, coupled with policies of total fire suppression by large public land managers in the western U.S., caused a dramatic decrease in natural, low-severity fires since the late 1800s and an increase in destructive mega-fires (Hessburg and Agee 2003). Whereas the combination of natural and anthropogenic fires historically broke the landscape into heterogeneous patches having diverse fuels, twentieth century forest management characterized by total suppression has created more homogenous, contiguous forest and fuel beds. Consequently, forests that would naturally see frequent, low intensity fires now exhibit conditions that are more conducive to large and severe wildfires. Following this, the annual area burned by wildfire has grown in the U.S. over the past thirty years. Consequently, the program required to suppress and manage these fires now demands more than $\$ 2$ billion annually.

The staggering threat of environmental degradation from wildfires and other disturbances has prompted researchers and land managers to attempt to more fully 
understand human ecological impacts in the past in hopes of managing today's natural resources and landscapes with more breadth and authenticity. A broader understanding of indigenous resource management, especially anthropogenic fire, has become an important topic not only in anthropology and the biological sciences, but also for ecological restorationists. These restorationsists must convince government agencies, and in turn the public, of the necessity of using controlled and prescribed fires to reduce fuel loads, restore rare and endangered species, and reestablish and maintain biodiversity while simultaneously lessening the horrendous costs and extreme hazards that all too frequently derive from high-intensity wildfires.

\section{The Dinkey Landscape Restoration Strategy}

Within the SNF and located about a fifty-mile drive east of Fresno, CA, lies a creek that early settlers named after a little dog in August 1863. One day that month, a group of hunters was surprised by a large, angry grizzly bear. The hunters' little dog, Dinkey, barked and rushed up to challenge the bear. The grizzly swatted the dog away, but Dinkey's attack distracted it long enough to allow one of the hunters to grab his gun and shoot the bear. Dinkey died from his wounds, but the hunters named the nearby creek after the little dog to honor its bravery (Browning 2011).

Dinkey Creek and the surrounding area look strikingly different today than the open, park-like landscape that supported grizzly bears in 1863. More than a century of intense fire suppression on the Dinkey Collaborative landscape (Figure 3) and throughout the Sierra Nevada has resulted in an overcrowding of conifers and a thick, fire-prone understory. A legacy of antagonism and litigation has stagnated restoration efforts and 
stimulated the development of the Dinkey Collaborative and its subsequent landscape restoration projects. The restoration strategy is both a landscape- and stand-level approach that acknowledges that fire is the dominant ecological process influencing ecosystem processes and vegetation dynamics. Coniferous forests, foothill hardwood forests, meadows, and riparian zones together create one integrated, fire-adapted landscape that requires a flexible and adaptive restoration strategy that promotes fire resiliency. Using prescribed fire, mechanical thinning, watershed improvements, and other restoration treatments, the project seeks to restore key features of diverse, fireadapted forests, including heterogeneity at multiple scales, reduced surface and ladder fuels, and terrestrial and aquatic habitats for sensitive wildlife species. The restoration strategy is intended to foster a landscape that is resilient to uncharacteristic wildfire, insects and disease, climate change, drought, invasive species, and air pollution (USDA Forest Service 2010). Further, this restoration strategy is one that implements collaborative treatments to achieve multiple goals: reducing hazardous fuels, retaining and promoting large tree and denning/nesting structures needed by the Pacific fisher and California spotted owl, promote stand and landscape heterogeneity, and provide sufficient natural regeneration of shade-intolerant tree species for the creation of future fire-adapted forests.

Today, the Dinkey Collaborative is nearing the end of its initial ten year budget plan. And as its participants seek out further funding through grants and other sources, it seems appropriate to examine the effectiveness of this collaborative turn in forest management punctuated by the CFLRP and the Dinkey Collaborative. For the sake of this study, 
particular interest is paid to the collaborative nature of the Dinkey Landscape Restoration Strategy, and how tribal participants within that collaborative contribute to the implementation of restoration strategies. 


\section{Chapter 4: Approaches to Historical and Traditional Ecology}

In this section, I discuss the conceptual frameworks that inform this study. First, I examine the long history of human-nature dependencies in the Sierra Nevada that inform historical ecological models, and how a recognition of such may or may not drive contemporary approaches to land management. Next, I briefly explore the state of anthropological and archaeological research on pre-Columbian resource management in the Sierra Nevada. Particularly, I pay close attention to how this historical ecological data is important for informing contemporary forest management. I then explore the base of traditional ecological knowledge, how it articulates with scientific ecological knowledge, and why it matters for contemporary forest management.

\section{Historical Ecology}

It is central to this study to understand the broad spatio-temporal interactions that inevitably occur between people and ecosystems: that humans in California's Sierra Nevada interacted with plant and animal species for upwards of 12,000 years, inevitably establishing certain human-species dependencies. In this way, humans can have a cascading effect on an ecosystem that promotes the stability, persistence, and resilience of a given environment (Codding and Bird 2013). Because of this, it follows necessarily that removing millennia of human-initiated disturbances from certain landscapes would cause profound environmental changes. It was over thousands of years that humans ceaselessly entangled themselves with nature through their vast knowledge and practical experience (Hodder 2012). In the process, they maintained, enhanced, and in part created a landscape that was mistaken as "wild” by European and Asian farmers, ranchers, and 
entrepreneurs, who claimed to have built civilization out of a remote, people-less land. Any concept of pre-contact California as an unspoiled, raw, uninhabited wilderness effectively discounts Native Californians and their history with the land and dispossesses them of their tremendous biological wealth. As environmental historian William Cronon writes, "The removal of Indians to create an 'uninhabited wilderness'—uninhabited as never before in the human history of the place-reminds us just how invented, just how constructed, the American wilderness really is” (1995:79).

Furthermore, this lasting misconception of wilderness in the U.S. has distorted interpretations of some of the country's most coveted Western landscapes. With the increasing loss of biodiversity, degradation of ecosystems, and the endangerment of particular species in California, public and private institutions have responded by setting aside land and protecting it from nearly all human influences. The assumptions behind this strategy are apparent in the way we define wilderness. According to the 1964 Wilderness Act, wilderness is

an area where the earth and [its] community of life are untrammeled by man, where man himself is a visitor who does not remain. An area of wilderness is further defined to mean in this Act an area of undeveloped Federal land retaining its primeval character and influence, without permanent improvements or human habitation...and which...generally appears to have been affected primarily by the forces of nature, with the imprint of man's work substantially unnoticeable. [Public Law 88-577]

Clearly, the focus here is on the absence of human influence. However, there is evidence that much of what we consider wilderness today was impacted by thousands of years of Indian burning, harvesting, tilling, pruning, seed broadcasting, and tending (Anderson 2005; Blackburn and Anderson 1993; Lewis 1993). 
Much of the misconception around wilderness derives from simplistic models of California hunter-gatherer societies as merely opportunistic foragers, as well as a shameful disregard for their deep history and knowledge of physical environments, as well as their deliberate, tempered use of nature (Anderson 2005). It is this long interaction with a variety of natural resources that ecological landscapes were altered, ultimately forging widespread dependencies and exponential entanglements. This is not to say that setting aside areas as wilderness is not necessary given our growing population numbers, but that there are compelling reasons to protect, restore, and manage some wildlands by following a model other than the hands-off wilderness approach.

A more nuanced, historical ecological understanding of past human involvement on various landscapes not only reveals how human ecological adaptation brought us to where we are, but also how to restore ideal environmental conditions. This suggests that there might be alternative ways of conserving our public lands, particularly vis-á-vis anthropological and archaeological investigations of indigenous land management practices. In the next section, I discuss some of the investigations that account for our knowledge of indigenous resource management in the past and thus enrich any application of indigenous management perspectives and practices today.

\section{Anthropology, Archaeology, and Indigenous Ecological Management}

By studying how indigenous people of California appropriated plants and animals for cultural uses while also allowing them to flourish can aid restoration actions today. Historical accounts contain many descriptions of Indian practices on precontact landscapes in California. Some of the most effectual management techniques involved 
burning, pruning, tilling, weeding, and selective harvesting. Although detailed analyses of ethnographic and historical observations have led to major contributions to our understanding of indigenous ecological and resource management strategies (Anderson 2005; Blackburn and Anderson 1993; Deur and Turner 2005; Fowler et al. 2003; Turner and Peacock 2005), there is still considerable debate about the magnitude of such practices and their overall impact on the environment in California. Some researchers, for instance, argue that the scale of environmental modifications is greatly exaggerated in the current anthropological literature (Vale 1998). In response, some innovative archaeological research is beginning to contribute to these debates but there has been little systematic movement to incorporate past indigenous land management implications into the method and theory of hunter-gatherer research in North American archaeology. This is problematic if our goal is to reveal pre-contact particularities, especially considering that most the anthropological research on indigenous management practices is derived from post-contact historical and ethnographic accounts. It is challenging because there is a lack of the kind of evidence required to empirically represent ancient anthropogenic burning strategies. For example, although some of this ethnohistorical research (Anderson 2005; Blackburn and Anderson 1993; Lewis 1993) has provided a great deal about the existence of anthropogenic burning, as well as the different reasons California Indians may have used fire strategically, there are still limitations in relying primarily on these sources to study prehistoric practices. Nonetheless, these kinds of investigations are important for contemporary forest restoration in that they clarify the 
various impacts indigenous peoples had on past environments and inform current analogs.

\section{Traditional Ecological Knowledge in Land Management}

In this thesis I emphasize the experiences and perspectives of local tribal communities within the Dinkey Collaborative. Through a deep knowledge of the areas in and around the SNF, local tribal communities offer a traditional ecological knowledge (TEK) base that spans thousands of years. TEK refers to the knowledge, practice, and belief concerning the relationship of plants and animals to the physical environment held by people with a direct dependence upon local resources (Berkes 1999; Kimmerer 2002; Rossier and Lake 2014). The use of traditional landscape management practices altered pre-European landscapes throughout North America, especially through landscape burning practices (Blackburn and Anderson 1993; Stewart 2002; Vale 2002). California and the Sierra Nevada are no different, as Native American land management shaped many of California’s signature ecosystem types (Anderson 2005).

TEK is not unique to Native American culture, but exists throughout the world, independent of ethnicity. TEK is recognized as rational and reliable knowledge that has been developed through generations of intimate contact by native people with their lands (Anderson 2005; Mauro and Hardison 2000). Internationally, TEK holds equal status with scientific knowledge [UNEP 1998] and has been termed the "intellectual twin to science” (Deloria 1995). This intellectual tradition exists in parallel to scientific traditions, yet has been historically marginalized by the scientific community (Salmon 1996). 
TEK and scientific ecological knowledge (SEK) share much in common (Rossier and Lake 2014). Not surprising since both traditions derive from the same source: systematic observations of nature. Both knowledge systems yield detailed empirical information of natural phenomena and relationships among ecosystem components. Both SEK and TEK have predictive power, and in both intellectual traditions, observations are interpreted within a particular cultural context (Kimmerer 2002).

TEK includes a wide range of biological information which overlaps significantly with the content of a common course in ecology or conservation biology. The scope of TEK includes detailed empirical knowledge of population biology, resource assessment and monitoring, successional dynamics, patterns of fluctuation in climate and resources, species interactions, ethnotaxonomy, sustainable harvesting, and adaptive management and manipulation of disturbance regimes (Berkes 1999). Case studies of the utility of TEK in conservation biology span a range of biomes from the tundra to the tropical rainforest (Berkes et al. 1995; Fernandez-Gimenez 2000). Because of the evidence, land managers today often recognize TEK's utility or at least acknowledge Native Americans' long-established interrelationship with landscapes that existed before the arrival of Europeans (Anderson 2006; Anderson and Barbour 2003; Rossier and Lake 2014).

Through an emphasis on traditional or tribal perspectives, I do not intend to privilege one group of stakeholders over another. Rather, it aims to evaluate a perspective (or perspectives) which has been historically marginalized despite the overwhelming validity of its merit. The native cultures who hold traditional knowledges are likewise endangered in part because of the obstacles often faced in continuing cultural traditions: a lack of 
access to traditional gathering sites, and the degradation of plant quality, soil fertility, and biological diversity (Anderson 2005). Also, tribal stakeholders assume a primary focus of this study because of their unique statuses as sovereign entities and special governmentto-government relationships with agencies such as the USFS, the Bureau of Land Management, and the U.S. Fish and Wildlife Service. Essentially, Indian tribes are distinct from all other stakeholders (Getches et al. 2011) and the study described here operates accordingly. 


\section{Chapter 5: Methodology}

This study explores the apparent ambiguities surrounding the theoretical and practical dynamics of tribal collaboration within forest restoration projects such as the CFLRP. The study isolates the complexities that occur between one tribal group — the NFM-and

a federal agency — the USFS — in the planning, implementation, and monitoring phases of one collaborative group: The Dinkey Collaborative. I take an ethnographic approach, utilizing participation in collaborative fieldwork and meetings, unstructured and semistructured interviews, and literature review to illuminate tribal and agency perspectives and elucidate the mechanics of collaborative processes in contemporary forest restoration projects. To accomplish this, I focus on three research questions. First, how do tribal and agency participants conceptualize collaborative implementation? The CFLRP’s relatively novel requirement of collaborative implementation creates tensions in the collaborative process, buoyed by administrative and bureaucratic constraints. Because of this new layer in the adaptive management process, it is expected that there will be significant differences between tribal and agency participants in the conceptualization of collaborative implementation. Second, how do these participants conceptualize ecological restoration in practice? While there may be general agreement on the outcomes of restoration actions, the rationale, methods, and desired ecological outcomes may differ significantly.

\section{Project Objectives}

The Dinkey Collaborative offers an opportunity to explore questions relating to the practice and theory of collaborative implementation in public lands management 
involving tribal stakeholders. A key point of inquiry for this examination is how tribal and agency participants conceptualize collaborative implementation in practice. Collaboration within the implementation process is a key component of any CFLRP project. Until recently, implementation was typically left up to the USFS (or other agencies), yet through a focus on collaborative implementation, CFLRP legislation creates a new layer in the legal context of agency collaboration. As such, implementation in the Dinkey Collaborative requires exploring new opportunities for stakeholder participation in forest management processes while adhering to preexisting legal requirements in National Forest land management. Following the results of similar research (Butler et al. 2015), I expected that, while the policy process is typically described as a cycle that starts with the planning phase, followed by implementation and monitoring, tribal and agency participants will conceptualize collaborative implementation in practice differently than is intended by the CFLRP.

I also seek to identify what tribal and agency participants think restoration itself ought to look like in the Dinkey Collaborative. Disparate groups within the Dinkey Collaborative ostensibly strive together for a goal of forest restoration. However, what this restoration looks like in practice for different groups may be significantly different. For this, I am keenly interested in how tribal and agency participants conceptualize restoration in practice. This question builds on similar inquiries into collaborative groups like the Dinkey Collaborative. For instance, one researcher (Hutchins 2005) has shown that, while there may be some overlap in participants' conceptualization of restoration, disagreement on important social topics related to restoration such as public involvement 
and social and economic goals remains, as well as significant variation on topics such as the appropriate balance between social and ecological goals. In addition, there is evidence that CFLRP partnerships have primarily focused on areas of high agreement among stakeholders but have not yet addressed some areas of conflict identified by participants as future challenges. To fill a knowledge gap, I hypothesize there will be significant variation between different collaborative participants' conceptualization of restoration in practice.

I am also interested in how tribal and agency participants conceptualize the rationale, method, and ecological outcome of restoration efforts. By identifying various rationales, methods, and ecological outcomes of tribal and agency management approaches, areas of agreement can be established to foster more effective partnerships that enhance mutual goals of cultural and natural resource vitality, improved ecosystem services, and tribal sovereignty. I expect that while there will be a handful of discrepancies between tribal and agency conceptions of the rationale, methods, and ecological outcomes of restoration efforts, sufficient overlap will exist among them.

\section{Sample}

I employ a purposive sampling approach intended to focus time and resources towards informants who hold the most pertinent knowledge on the topic at hand. While a diverse range of informants constitutes a more complete sample in most contexts, selecting informants with a knowledge of collaborative forest management and restoration, let alone traditional methods of management, is paramount in this endeavor. A purposive sampling technique is a type of non-probabilistic sampling that is most 
effective when one needs to study a certain cultural domain with knowledgeable experts in it (Tongco 2007). While inherent bias exists within this sampling method, it is this bias that contributes to its efficiency. That said, I established comprehensive sampling variables that negotiate a need for rigidity with a requirement of depth.

I focused my sample on six individuals within the Dinkey Collaborative, as their involvement in a collaborative forest restoration group implies they possess specialized knowledge in this environment. My key informant, NFM Tribal Chairman Ron Goode, is widely noted as a knowledge expert in traditional resource management and its application in forest restoration. He has written several scholarly articles on the subject, and has contributed to influential research and publications, including Stanford University’s Comparative Wests Project and Kat Anderson’s Tending the Wild (2005).

To maintain a manageable dataset that could still meet my project objectives, I limited my sample to agency and tribal participants in the Dinkey Collaborative. Agency participants from the USFS consist of an archaeologist, wildlife biologist, tribal liaison, and fire manager. Tribal participants were represented by Goode and an environmental coordinator from another nearby tribe. All participants were selected because they were present at or involved with Dinkey Collaborative meetings, project undertakings, or else were mentioned in discussions with key informant Goode. These agency participants hold decades of experience contributing to and researching landscape-scale, collaborative land management projects in both the Sierra Nevada and in federal agency settings. All agency participants' identifying information is withheld to avoid professional or ethical conflicts and only general information such as departmental position is included here (e.g., USFS 
scientist, USFS fire manager, USFS administrator). Interviews were guided by a predetermined set of questions (Appendix B). Key informant Goode’s name and recorded interview are included in this study (Appendix C), only after consent was given according to a formal request for participation (Appendix A). Goode’s perspective is not intended to represent all tribal perspectives, but is instead one viewpoint from one individual that holds a vast knowledge of forest restoration and land management in both traditional and modern contexts.

\section{Participation in Meadow Restoration Projects}

I gathered a large portion of data through ethnographic participation in meadow restoration projects on the SNF involving tribal, agency, academic, and public volunteer participants. These meadow restoration projects meet multiple objectives for multiple parties. For instance, the opportunity to restore certain meadows within the SNF offers tribal groups such as the NFM and other nearby tribal representatives to be active stewards of their ancestral territories while providing employment openings for some through grants and other funding opportunities. Many, though, participate out of their own generosity, hoping to make connections with the land and contribute to a worthwhile endeavor. For agency participants, the projects represent a chance to accomplish administrative and professional goals while fostering productive, collaborative relationships with groups who likely feel disenfranchised by local, state, and federal agencies. It should be said, though, that some agency participants are monetarily compensated for their participation in the Dinkey Collaborative, and this topic is considered in more detail in later chapters. Finally, academic participants were often 
present to fulfill curricular requirements, although it would be disingenuous not to note their overall enthusiasm for the goals and essence of the work.

\section{Interviews}

While no interview can be truly unstructured (DiCicco-Bloom and Crabtree 2006), many of the interviews employed in this study were unstructured and equivalent to guided conversations. This approach is not uncommon in anthropology and, in this case, I gathered data through participant observation in meadow restoration projects and recorded field notes as I participated in activities such as tree cutting, pile burning, biological monitoring, as well as the significant conversations that occur over lunch breaks. During these projects, I observed the actions occurring around me while asking questions of several informants, taking jottings and short notes during and after the event. Questions were intended to elicit information about the meanings of certain actions and perceptions, with further questions emerging over time as I learned more about the projects.

While I conducted the unstructured interviews in conjunction with the collection of observational data during my participation in meadow restoration projects, semistructured, in-depth interviews form a major data source for this project. Semi-structured interviews were scheduled in advance at a designated time and location outside of everyday events, although two took place over the phone. The interviews were organized over a set of predetermined open-ended questions (Appendix B), with other questions emerging from the dialogue between the interviewer (myself) and the interviewee. The 
use of semi-structured, in-depth interviews allowed me to explore certain matters more deeply, and often allowed the interviewee to expound on topics of their choosing.

\section{Data Collection and Analysis}

To meet project objectives, I employed a multiphase methodology that first utilized exploratory observation within the Sierra Tribal Forum to establish key informants and relevant themes for subsequent data collection. Next, I arranged to participate in meadow restoration projects to gather observational and unstructured interview data related to project implementation. The third phase involved an in-depth interview with NFM Tribal Chairman Ron Goode coupled with participation in a Dinkey Collaborative meeting. The final phase consisted of interview transcription and data analysis, focusing on themes established through ethnographic coding techniques.

In the summer of 2015, study informants were initially recruited through occasional tribal forums hosted by the SNF. These open meetings brought together representatives and stakeholders from multiple agencies, organizations, and tribal entities to discuss matters pertinent to the ancestral territories of twelve tribal groups now administered by the SNF. These meetings typically occur in SNF offices. The forum I attended took place in Bass Lake, CA and featured agenda topics ranging from post-wildfire restoration and tribal forestry, to the Dinkey Collaborative, itself. At the outset of the meeting, I introduced myself as a graduate student studying TEK. Through this meeting, I was introduced to Tribal Chairman Goode. Goode works regularly with the SNF on a variety of projects but is noted for his ecological management projects. Within these joint projects, the two parties collaborate to restore and maintain a handful of meadows, 
employing a collaborative approach with an emphasis on traditional ecological knowledge. In fact, at the time of this writing, negotiations are in the final stages to include and acknowledge tribal ecological knowledge in a Memorandum of Agreement (MOA) between the NFM and the SNF. To be sure, while the USFS is a colonial, capitalistic enterprise, inextricably entangled in and focused on profit and ecosystem goods and services, this draft MOA takes steps toward honoring tribal relationships to the land, site-specific relationships that members sustain in the forest, and acknowledges the historical reasons for disruptions in those relationships.

I planned with Goode to participate in meadow restoration projects during the summer of 2015 while I was living in nearby Prather, CA working as a seasonal field archaeologist for the SNF. I made it clear to Goode and others involved that I was participating in these projects strictly as a student researcher interested in observing collaborative meadow restoration activities in a participatory manner and took approved leave from my employment with the SNF on project days that occurred on regular work days. Both 2015 project days took place within the Texas Flat area on the SNF, lasting all day as Goode, NFM tribal members, interns from a nearby tribe, the Bureau of Land Management, academic interns, and USFS employees worked together to conduct biological monitoring, strategic tree thinning, and wood-chipping in and around the rich Texas Flat meadow system. I participated in two project days during that summer and was told that I could take notes for data collection purposes. Following each meadow restoration project, I asked questions, took extensive notes on the day's events and discussions, and anything else that stood out as relevant or important. 


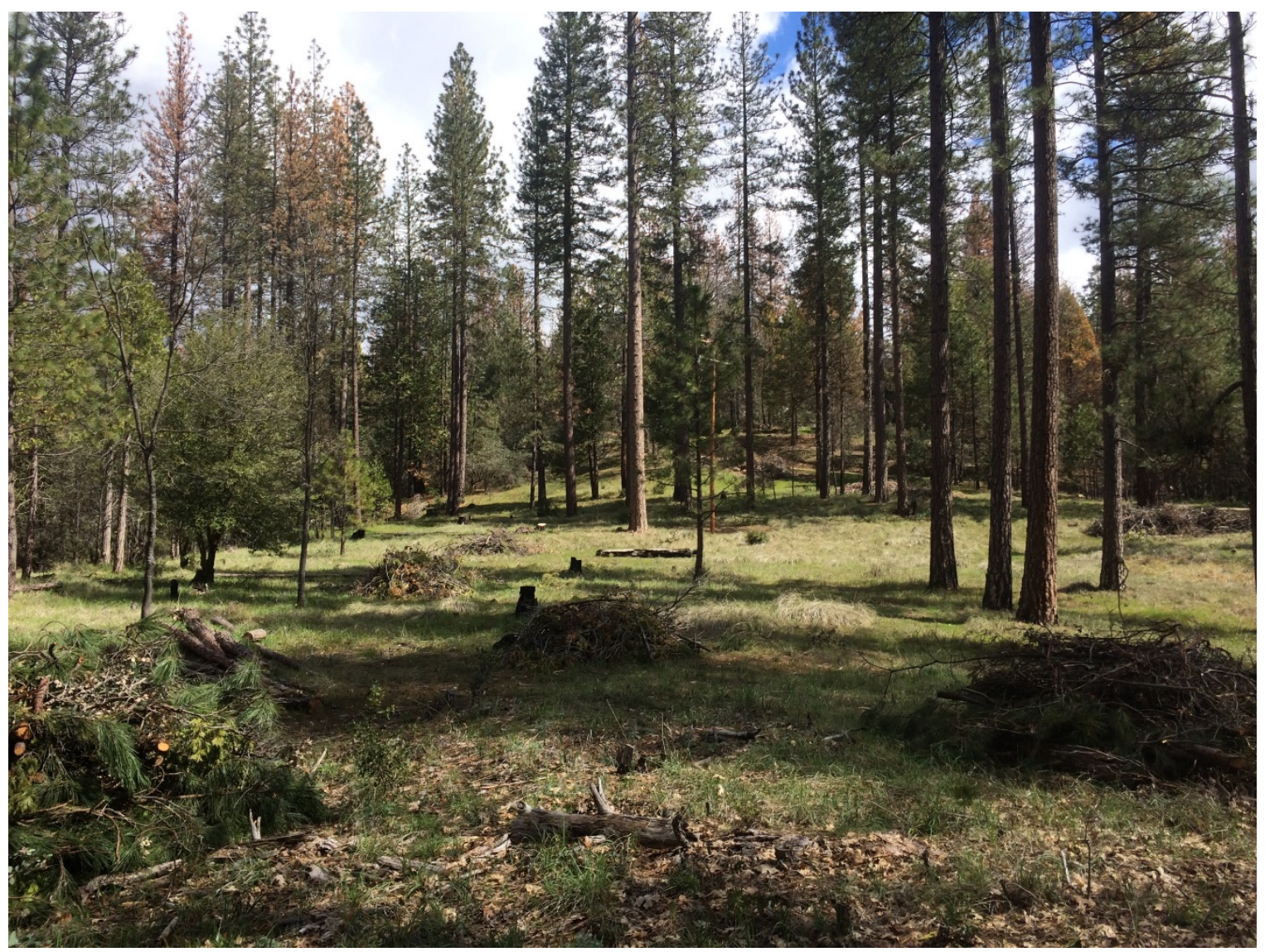

Figure 3. Crane Valley Meadow, Sierra National Forest

In the fall of 2015 and spring of 2016 I participated in two similar projects organized by Goode that took place in Crane Valley Meadow near Bass Lake, CA on the SNF

(Figure 2). The activities were like that of the Texas Flat restoration the previous year. The timing of the project days was convenient_-fall and spring—because they represent a time of major seasonal change and triggered important conversations with Goode and other participants about the results of the previous years' treatments, good times to burn the landscape, and other topics.

In December of 2016, I travelled to Fresno, CA to record an in-depth interview with Goode and attend a Dinkey Collaborative meeting at the SNF headquarters in Clovis, 
CA. The interview lasted nearly an hour-and-a-half and provided insight on Goode’s meadow restoration projects, his collaboration with the SNF, and the Dinkey Collaborative. The Dinkey Collaborative meeting, which took place the following day, was well-attended and lasted all day. The meeting was led by a facilitator from the Center for Collaborative Policy, and focused on funding opportunities, collaborative evaluations, fire management, and most importantly, tribal laws, policies, and partnerships.

The final phase of this study consisted of interview transcription and data analysis. The analysis focused on meadow restoration project notes, Goode’s interview transcript, official project documents, and CFLRP literature. I concentrated on themes established through ethnographic coding techniques. In this coding process, special designation was given to discussions of prescribed fire, project implementation, and restoration in practice. Cultural or prescribed burning assumes a significant role in the analysis because of its cultural and ecological importance to the NFM (Aldern and Goode 2015). I also coded for any mentions of project implementation that focused on land management treatments, treatment methods, timing of treatments, or obstacles to treatments. Additionally, I highlighted text relating to collaborative implementation, collaborative restoration in practice, and rationale for restoration using a thematic coding scheme. The analysis isolated areas of tension and overlap between agency and tribal participants and in this way I am able to compare various emic conceptualizations held by tribal and agency informants. In the following chapters I present these areas of tension and overlap. 


\section{Chapter 6: Results}

In this chapter I detail a handful of results derived from my interviews with agency and tribal participants as well as participation in meadow restoration projects and a Dinkey Collaborative meeting. Agency participants include a USFS fire manager, archaeologist, wildlife biologist, and tribal liaison. Tribal participants include North Fork Mono Tribal Chairman Ron Goode and an environmental coordinator from a nearby tribe. Through their accounts, I present conceptualizations of the collaborative process, especially pertaining to collaborative implementation, ecological rationale, methods, and outcomes, and restoration in practice. I begin by describing the conceptual differences that exist between agency and tribal participants in regard to collaborative implementation. Particularly, I found significant points of both pressure and overlap between Goode and a USFS fire manager and include the perspective of a USFS tribal liaison that focuses on the opportunities provided by collaborative implementation. Next, I depict the differences between tribal and agency participants over the ecological rationale, methods, and desired outcomes of project undertakings. I focus on the perspectives of Goode and a USFS wildlife biologist that highlight policy constraining

the use of TEK in collaborative projects on USFS lands. I supplement the perspective of a USFS archaeologist that further highlights organizational constraints to incorporating TEK as an perspective in adaptive co-management. I then focus on the differing conceptualization of restoration in practice, especially in the NFM's pursuit to conduct cultural (prescribed) fires on the SNF. I conclude the chapter by looking forward and 
briefly considering what these results may mean for collaborative processes involving tribal and agency participants.

By analyzing interview data and meadow restoration project notes, I found several points of tension in the implementation phase of project undertakings. Differences in the conceptualization of collaborative implementation are apparent in the testimonies of both tribal and agency participants. For instance, tribal and agency participants had contrasting conceptions of what collaborative implementation ought to look like, primarily over whether collaboratively-informed implementation was sufficient to meet CFLRP requirements. The data show, also, that there are serious consequences to not collaborating fully during implementation that threaten the efficacy of the entire collaborative project.

Differing conceptualizations of the rationale, methods, and ecological outcomes of restoration treatments exist, as well. Especially in the conflicting desired outcomes of fire managers and some wildlife biologists, consensus is hard to find and projects are handicapped from the start by multiple, contradictory objectives. Even further, when areas of overlap or consensus do exist, it became evident that restoration in practice nonetheless becomes muddled. Especially for issues such as the application of prescribed fire to the landscape, most participants agree on the rationale, methods, and desired outcomes. However, implementation often faces obstacles like air quality restrictions.

\section{Collaborative Implementation}

I expected that tribal and agency participants would conceptualize collaborative implementation and monitoring in practice differently than was intended by the CFLRP. 
In this way, considerable differences do exist, particularly in perceptions of how implementation ought to be accomplished. Agency participants appeared to conceptualize collaboratively-informed implementation and monitoring as sufficient for meeting Dinkey Collaborative requirements, while tribal participants considered implementation and monitoring as a truly collaborative process only when the actions were taken in-part or solely by tribal collaborators. Further, the way implementation actions are undertaken is incommensurate with tribal participants' conceptualization of collaboration, notably in the differing financial incentives available to disparate individuals and groups within the Dinkey Collaborative.

The USFS fire manager that I interviewed expressed an opinion that while truly collaborative implementation is a "novel" idea, it is simply unrealistic. While collaborative planning is "logistically possible," collaborative implementation is not. He did concede, though, that certain actions on the landscape are better suited to collaborative implementation. For instance, he said that implementation actions such as forest thinning, in which small diameter trees are removed from dense forests, are easier to conduct collaboratively, while actions such as prescribed burning are far more difficult to accomplish in this way. When asked why, he cited safety and accountability as main reasons. In this sense, it understandable why any fire manager would be apprehensive to add further layers of complexity to the social dynamics of wildfire risk and mitigation (Charnley et al. 2015) by including collaborative participants who may not be bound to the same systems of accountability and authority as federal agency fire managers. 
How the actions should be undertaken is the first clear difference in the conceptualization of collaborative implementation between agency and tribal participants. While management actions taken on the landscape are often informed by a collaborative planning phase, actual implementation is not accomplished cooperatively, involving multiple stakeholders in the actual act of implementation. For instance, in our discussion, Goode despondently recalls damage inflicted on a culturally-significant grove of black oaks that was under-burned incorrectly by a USFS fire manager:

He went out and burned 780 acres under the oaks, he told [my colleague] 'Oh I read Ron Goode's cultural burning article, I'm good to go.' So, yeah, he burned up all the oaks, a couple - two or three-are gone...And why? Because they don't prep. No preparation. You can't take a weedeater and go out there and cut around the oaks? When you're gonna burn that's what you do. You go out and clear the ground. Then you burn. And everything that comes off the old limbs and what you rake up, that you burn in the piles underneath the oaks so it gets good smoke, some heat, and then you broadcast burn around it and it won't burn the oak. But no, they can't do that. And the [USFS fire manager] that was out there, she...killed twelve to fifteen oaks. They're not coming back. (Goode)

Goode was also incredulous about the way project implementation is often initiated collaboratively, yet completed independently. In one instance, he described how preparation for a burn was conducted collaboratively, but the actual burning and mop-up was not. Goode and other collaborative participants removed small trees and brush from the outskirts of Texas Flat meadow, placed them in "piles all throughout the meadows and on the edge of meadows, so [they] can burn them.” The idea here, he says, is that when you're burning,

...you can go from one pile to the next, you can burn several at once. And when you get done you have to fix your ash piles and winter comes-if you have water, you're good — and then it grows back nice and lush. But they wouldn't let us burn our piles, so last year on the North Fork side [of 
the SNF], one of the [USFS fire managers] took her crew out there and she burned 50 of our piles, but never finished them. So, June came and we went out and she was all proud of her burning, and the first thing my nephews all said was 'We couldn't see where you burnt. It should be all lush vegetation. Flowers and plants_-food plants_-and medicine. Everything that grows out here should be growing right here. Not your ash pile, it shouldn’t still be there.' (Goode)

Goode was not consulted about the burning operation conducted by this USFS fire manager, and thus was not given an opportunity to provide knowledge or labor throughout the entirety of this implementation activity. He expressed displeasure at the failure to work collaboratively with the SNF, that many of the restoration goals set out initially had not been met. "We’ve gone out to see meadows, we’ve gone out to see oaks; and then the new fire man there in the Dinkey, he went out and burned one of those plots that we said needed burning, but never invited any of us. And afterwards: 'Oh, I burned and it didn't quite come out so good'...There's absolutely no point at all what you just did if you're not going to work with us.”

A major difference in the conceptualization of collaborative implementation between agency and tribal participants exists, especially on the topic of what collaborative implementation actually looks like. On the one hand, tribal participants feel it is necessary to collaborate throughout the project process, especially during collaboration, while agency participants have a different view. A USFS fire manager stated that collaboratively-informed implementation should be sufficient, yet Goode and other tribal participants felt that for implementation of project undertakings to be truly collaborative, they ought to be conducted either in combination with or overseen by tribal participants. The outcome in several instances was the incorrect application of traditional ecological 
knowledge and methods, resulting in harmful effects to traditional cultural places like oak groves and meadow systems. Goode showed great frustration when describing the disconnect between tribal and agency participants on the issue of collaborative implementation, so much as to explain that he is unsure whether he will attend future Dinkey Collaborative meetings. From these various accounts, it becomes clear that there are differing conceptions of what collaborative implementation ought to resemble in practice.

The tensions surrounding collaborative implementation take on a greater role considering my interview with a USFS tribal liaison. He argues that while the issue of collaborative implementation can be quite difficult to truly accomplish, it offers the greatest opportunity for Native American participants and deserves more attention. According to him, besides priorities such as health, housing, elder care, and emergency planning, the greatest priority is employment. As he sees it, “jobs, jobs, jobs” offer the greatest potential value for Native American collaborators in Dinkey Collaborative undertakings. He envisions a Native American workforce in the area that works collaboratively with the USFS to implement restoration projects, not unlike tribal fire crews that are common in wildfire incidents today. In this way, he argues, multiple project objectives can be met with the greatest benefit for all parties and stakeholders involved.

\section{Ecological Rationale, Methods, and Outcomes}

Goode talked during our meadow restoration days and in-depth interview about differing conceptions of how to best manage threatened and endangered species like the 
Pacific fisher or California spotted owl. He often espoused the need for strategic thinning of conifers in and around SNF meadows. Part of his reasoning is rooted in stories handed down from generation to generation. For instance, at one meadow restoration day, he explained to me that his ecological view is one characterized by an "open-forest" or "open-view" policy. An open, park-like forest, unlike many of the dense forests seen today in California, is better for all animals, because it generates food sources at the bottom of the food chain. As he described, "wherever deer goes, mountain lion goes; and wherever lion goes, bear is sure to follow." This is emblematic of the kind of holistic view he takes, often considering much more than habitat and extrapolating to the broader food chain. Goode also noted that the "open-forest” policy passed down through successive generations is also social in nature: simply, it offers protection, as it is easier for elders to see through the forest and perhaps watch where their children are playing. Nonetheless, collaborative land managers are forced to negotiate between differing perspectives, yet overlap may be found in a greater focus on areas of agreement such as endangered species’ prey.

Goode shared similar sentiments about USFS policies that nearly led to catastrophic tree mortality and environmental degradation in a culturally significant portion of the SNF during the 2013 Aspen Fire. The difference this time is that it concerned the notorious spotted owl. As Goode describes it, this area overlooking Mammoth Pool Reservoir used to be open, with conifers at least 200 years old and oaks nearly 400 years. That was until 1991 when an owl was heard in the area by USFS wildlife biologists. According to USFS policy, areas where owl calls are heard—even once—are then 
managed to preserve a dense understory to accommodate more favorable owl habitat.

Goode describes a conversation he had with a USFS employee during a post-wildfire

field trip following the 2013 Aspen Fire:

Then we got down to the next stop, Mile High Campground, and one of my members had a picture of him in a baby basket propped-up against one of the trees. So we can clearly see what it looked like back in the 1950s, how open it was. You know, the conifers were probably two hundred years old and the oaks pushing three to four hundred and the question that came up to the Ranger was 'Well what happens if the Aspen Fire would've jumped the river?' He said 'It would've came right up that draw right there and it would've wiped all this out'... This undergrowth is twenty-five years old. and he said 'Yeah, because we heard an owl hoot here'. Well, I said, 'I'm only an archaeologist, but I know for a fact that owl doesn't live for hundreds of years, but if an owl is continually coming back to an area and this is his nest, then how old is his nest?' He said, 'He don't have a nest, we just heard him hoot here'. [laughs] And for that you drew a circle on a map and said 'Leave this area alone'? Two hundred year old conifers and three to four hundered year old oaks and you want to destroy it. 'Well, we're not trying to destroy it, we're trying to protect the owl'. Then I say, 'Yea, and the man just got done telling you that the Aspen Fire would have destroyed it, you know?' 'Well, you know, this is our policy'. I say, 'Oh, OK. So when a fire does come through here, what's going to happen?' 'Well, the owl doesn't have a nest here so he won't be here' Oh, lordy! Very good, because now you left a density to let the conifers to get burned up, the oaks to be burned up. Because otherwise they would be open enough that a fire would burn through them. But now they can't. (Goode)

The conversation Goode is describing took place in June 2014. Later that same summer, just as he worried, another fire — the French Fire- did indeed jump the San Joaquin River, resulting in almost total tree mortality on that ridge, caused in-part by the accumulation of dense fuel loads per regional Forest protocols. For implementing policies such as the one described above, Goode directs much of the blame on agencies like the USFS and the US Fish and Wildlife Service: "You did that," he says referring to agency administrators, “you put that understory there!” 
For Goode, his ecological approach is more realistic than those of agency administrators within the Dinkey Collaborative. He suggests that they have a myopic view of ecological rationale and outcomes, that even after six or so years of the Dinkey Collaborative's existence, "it’s getting very hard for all of them to see the whole picture". The problem, as he sees it, is that many in the Dinkey Collaborative present research that is 'based on basically what they see in front of them. They're not doing research on hundreds of years of observation and knowledge".

This parallels the perspective provided in my interview with a USFS wildlife biologist, who discussed the inherent difficulties of making landscape management decisions based on TEK. She expressed her belief that the ecological knowledge derived from local and traditional sources is legitimate, however "it will never pass the test of best available science” (BAS). In an environment where restoration projects on USFS lands are heavily scrutinized and routinely litigated by outside parties, land managers must support and justify their decisions by utilizing BAS. "Simply", she said, "TEK is not widely regarded as the best available science”. Recent research (Charnley et al. 2017) validates this dilemma, as various land management policies and regulations require agencies like the USFS to employ BAS in decision-making, yet this typically occurs from the standpoint of best available natural science. The wildlife biologist I interviewed concurred, saying that perhaps social science sources depicting TEK perspectives are incommensurate with the evaluative criteria for BAS in most cases.

As I discussed earlier, archaeologists have a unique role in informing land management decisions by providing historical and anthropological perspectives on land 
use and resource management. In this case, archaeologists involved in the collaborative process ought to be promoting the scientific validity of traditional ecological knowledge systems and tribal connections to project landscapes that occur on ancestral tribal lands. The USFS archaeologist I interviewed shared that USFS Heritage Programs (the departments that handle cultural resource issues) tend to have a narrow scope of influence. It is this narrow scope, he says, that tends to constrain archaeologists' involvement in collaborative projects. For instance, he illustrated a strong dichotomy between natural and cultural resources in project planning. In this sense, USFS archaeologists are merely expected to provide guidance on complying with regulations such as the National Historic Preservation Act, Archaeological Resources Protection Act, and Native American Graves Protection and Repatriation Act, among others, and not necessarily provide any sort of guidance on historical ecological models or traditional land uses. For the USFS archaeologist I interviewed, there are strong organizational constraints that compartmentalize archaeologists' and anthropologists' to providing input only on cultural resource matters. However, this is in contrast with tribal perspectives that draw a rather thin line, or none at all, between cultural and natural resources, often considering them part of the same whole.

Data derived from both Goode’s recorded interview and his meadow restoration projects suggest that, while a consensus exists among tribal and agency participants regarding the need to reapply controlled fire to the landscape, there are still considerable differences in the rationale for burning. As Goode sees it, "the reason [agency participants] put fire on the land is to be paid for it. That's it. The more fire they put on 
the land, the more they get.” In his recorded interview, Goode echoed a sentiment he also expressed at one of our meadow restoration projects at Texas Flat. On that day, he expressed his surprise when told by a USFS fire manager that "We burn for acres; you burn for resources”. This statement encapsulates the elemental difference between “cultural fire” versus "prescribed fire”. In the words of the Southern Sierra Prescribed Fire Council, the former is "the knowledgeable and skillful application of a planned ignition in specific environmental conditions (e.g., fuel moisture, temperature, smoke dispersion, topography etc.) to achieve [specific] resource objectives.” The major difference between cultural and prescribed fire, as described by Goode and others, is that prescribed fire may be more narrowly focused on fire resiliency, while indigenous groups have employed cultural fires for generations to sustain plant and animal communities, especially the cultural assets (food and materials, as well as aesthetic and spiritual resources) within those communities. If one takes out the need to burn based on reducing fuel loads, Goode asks “Now why are you burning?”

A major chasm exists in the rationale and ecological outcomes of restoration, especially between Goode and the "wilderness people”-his term for environmental organizations concerned with preserving areas for federal Wilderness status and a preservationist approach. Tribes, including the NFM, typically fight Wilderness designations on National Forest land because it establishes a hands-off management approach that is in direct conflict with tribal assertions that these same lands were managed by Native peoples for millennia and require continued management to maintain 
a productive, dialectical relationship with the land. When asked why the NFM do not want more Wilderness by an agency participant, Goode responds

because you guys think that—and it even says right there in the plan—you don't do anything to it, so it won't cost you anything...So you just leave the land sick. No, that's not the way it was, that's not how you found it. We were able to go through here, and it was beautiful, you could still look at the meadows. And now you call it pristine? These things were all in place and we took care of them. It was where we lived. Trails that go through, you're still following our trails. They don't seem to get it. (Goode)

And while some National Parks are more progressive in their preservationist approach in Wilderness management (Anderson and Barbour 2003), Goode reminds us that "[National Forests] are not willing to change from whatever [the 1964 Wilderness Act] says, because it complies with how they view their financial attack.” In other words, the data shows that Wilderness designation is rationalized economically, rather than ecologically on National Forests.

\section{Restoration in Practice}

The NFM tribe faces opposition from many angles in their pursuit to apply fire to the landscape on USFS lands within their ancestral territory. Regulatory agencies concerned with air quality often lift burning restrictions for only two or three days, giving very little time for indigenous or agency firelighters to conduct a proper burn or even one that is large enough and therefore more ecologically impactful. "When you give them a window, keep it open, no matter what. Let them finish that project. Then that's done and you've got a big 400-, 500-, 600-acre piece done.” In my interview with the Environmental Coordinator from another nearby tribe, he emphasized the need for collaboration between tribes and agencies like the USFS, but stressed the inherent difficulties in doing so, 
particularly for activities such as prescribed fire which face intense regulation from a handful of local, state, and federal regulatory agencies. While there is a recognition on the part of the SNF and the Dinkey Collaborative to loosen burning restrictions derived from concerns about air quality in the nearby Central Valley, Goode still sees opportunities lost:

All of a sudden in April, the air pollution people just woke up one day and came to work and said 'OK...we're going to make some changes, and...one of them is when we open up the window we're going to leave it open. You've got until June $1^{\text {st }}$, so have at it!' [The SNF] didn't even try. They weren't even ready. But Sequoia [National Forest] did, Sequioa jumped on it and got a 750-acre burn right then and there. Took them seven days to burn it and boom, they were done. (Goode)

Not surprisingly, failures to act by agency participants begs Goode to question how the SNF utilizes restoration in practice; how the agency uses money awarded through the Dinkey Collaborative to fund projects that merely pay lip service back to the group, only accomplishing what the Forest wants. To be sure, it is not a surprising move by a large, under-funded federal agency to do such a thing, but Goode is moved to wonder where the people who contribute time, knowledge, and labor to such a Collaborative stand in the process:

As Native Americans-those of us that are there-we're all volunteers. I'm not getting paid. I don't get paid... But when we looked at the budgets that were coming out, and you see that the fire person is being supplemented \$37,000 a year... and it's not just one, there’s a whole list of them. Every time they go out, they charge the Collaborative. Well, what about us that are out here for the goodness of our heart, we don't get nothing...Then all the rest of these guys are getting paid? Paid to be here, paid to go out in the field? Paid to do their work?...When you see that it becomes really disheartening. What the hell am I doing? What are we doing here? (Goode) 
This point by Goode conjures a handful of critical considerations for the power structures operating within the Dinkey Collaborative. As designed, these sorts of collaborative groups aim, in theory, to decentralize resource management, giving not only voice, but also inherently the transfer of rights and responsibilities to local groups. The character — and by extension, success_— of CFLRP projects depend on an effective mix of rights and responsibilities being decentralized. Such empowerment is profoundly political, and, as Cruishank (1999) and others have argued, is neither good nor bad but “contains the twin possibilities of domination and freedom” (Kull 2004:248).

If local groups like the NFM only gain responsibilities, and few if any rights, then state power grows. The state, in the form of agencies like the USFS, penetrates further into society, and the decentralization process, despite its best intentions, becomes an expansion of bureaucratic power (Ferguson 1994). The situation Goode describes above illuminates the ways in which the USFS may co-opt local labor and time to its purposes. Similarly, Ribot (1999) documents a similar situation in the context of Sahelian forestry policies, whereby much of the decentralization process served to transfer only work, not power, to local levels, affording the state more microcontrol.

In the case of the Dinkey Collaborative, this thesis suggests that not enough rights are transferred. The state, in the form of air regulatory agencies, still has the deciding vote. This is because burning restrictions require other agencies like the USFS conform to existing legislation and rules as they pertain activities on its landscape. Thus, the NFM tribe's—or even the Dinkey Collaborative's—desire to burn an oak grove or meadow must still fall within the stipulations of regulations set by communities in the Central 
Valley. In this case, no rights have been transferred. For the Dinkey Collaborative to seriously change policy and ultimately work collaboratively with groups like the NFM, an entire suite of fire, forestry, and air regulatory laws must be reformed as well.

During the in-depth interview session, Goode was incredulous about collaborative failures during oak and meadow burning operations. I asked him whether a lack of knowledge or desire to collaborate was limiting the effectiveness of implementation. "It's a little bit of everything”, he responded, “because they tell me they’ve been trained by...one of the old Indian guys. Really? You missed a class someplace [laughs]. Oh, I don’t know. It’s just the frustration.” This interview took place on December 7, 2016. The next day, a Dinkey Collaborative meeting took place in Clovis, CA. Goode was not present and during the meeting I could not separate his absence on that day with his frustration with the Dinkey Collaborative. When asked if Goode believed the collaborative group was, after nearly seven years, still productive, he explained, "I think we're about done. That's what I think.”

\section{Moving Forward}

Despite this, the Dinkey Collaborative is regarded by many as a strong example of collaborative forest management in practice (Schultz et al. 2012). To the contrary, Goode sees a group of stakeholders who are not on the same page and who have yet to accomplish anything substantial.

"We all seem to be not on the same page. So, you go, and I try to go with an open mind and see what it is they're doing or what they're up to and the next thing I know, ah, man! I've been here for how many years? Coming to how many meetings? Where have we gotten? We've gotten nowhere...Then they come in with other studies from 24 other collaboratives, 'You guys on the [SNF], man you guys are the best! And 
everybody in the whole United States just thinks so much of what you guys are doing!' And I’m going 'No! This is pretty bad!' (Goode)

To more effectively manage the Dinkey Landscape, collaborative implementation needs to be taken more literally. The Dinkey Collaborative needs to foster more effective partnerships with local tribal stakeholders that involve actual collaborative implementation, not collaboratively-informed implementation. This would result in restoration treatments that are fully-informed by the diverse ecological perspectives that the Dinkey Collaborative is intended to foster in the first place. Second, it ought to involve tribal stakeholders throughout the entire project process, giving them an actual stake in the products of restoration activities, rather than preserving power structures that further disenfranchise tribal connections to ancestral homelands. Perhaps it would ameliorate at least some of the issues Goode and other participants have with the Dinkey Collaborative. "That's what the [CFLRP]—that Obama signed—was there for, to put people to work. Well, ain’t nobody working. Nobody's being put to work.” As the tribal liaison I interviewed stressed, it is about “jobs, jobs, jobs”. Creating employment opportunities through collaborative implementation would not only promote a truly collaborative outcome, it would uphold provisions set forth in the Indian Self Determination Act, wherein all federal agencies have a trust obligation to work with Indian tribes towards Indian self-determination. By faithfully including tribal entities in the exercise of their traditional knowledge base during implementation, agencies like the USFS would be restoring a land management approach that can be both culturally and ecologically successful. 


\section{Chapter 7: Conclusion}

In the preceding chapter I presented a handful of results derived from interviews and ethnographic observation within the Dinkey Collaborative. I found significant differences in the conceptualization of collaborative implementation, particularly in the way project undertakings should be accomplished. Between agency and tribal participants there were contradictory conceptions of collaborative implementation. For instance, agency participants conceptualized collaboratively-informed implementation as sufficient in the face of various logistical constraints. However, the two tribal participants espoused their conception of collaborative implementation as something that should be carried out in a concerted fashion, involving tribal stakeholders contributing to fieldwork and project undertakings. Likewise, the USFS tribal liaison I interviewed expressed the importance of tribal involvement in the implementation phases of projects not only for mutually beneficial outcomes, but also for local and tribal employment opportunities.

While there was some overlap in the various ecological rationales, methods, and outcomes of project objectives within the Dinkey Collaborative, the data show conflicts surrounding land management allocation policies. Competing rationales for endangered species management existed between tribal participants like Goode and the USFS wildlife biologist I interviewed. Further, even on a topic like prescribed fire, where consensus exists for an increase in its application to the landscape, there were differing conceptions between tribal and agency participants over the ecological rationale for prescribed fire. The difference was highlighted by Goode’s assertion that tribal participants burn for recourses, while agency participants burn for acres. Similarly, 
restoration in practice becomes muddled by various obstacles, especially when attempting to apply fire to the landscape. Tribal participants in the form of Goode and the tribal environmental coordinator expressed frustration over regulatory constraints that limit the Dinkey Collaborative’s ability to conduct prescribed burns. Further, tensions existed over apparent stipends that agency participants receive for their participation in the Dinkey Collaborative. This issue brings to the forefront significant considerations for the power structures involved within the Dinkey Collaborative.

The Dinkey Collaborative is in many ways a prototype for the adaptive and collaborative approach that the CFLRP was intended to promote. Nonetheless, a central tension that agency participants must negotiate is the degree to which they can collaborate during the implementation phase of projects, but also the extent to which they are willing to do so. I have emphasized the implementation phase of collaborative projects throughout because, as Gray (1989) agrees, collaboratives are more susceptible to collapse during implementation than any other phase. If conflicts within implementation are not negotiated during planning, implementation is guaranteed to pose new conflicts. And, as others (Ansell and Gash 2008) have pointed out, how to engage in collaboration within legal and organizational contexts of implementation has not yet been effectively sorted out. The Dinkey Collaborative shows that collaboration may be particularly challenging for agency participants as legal authority, systems of accountability, agency legitimacy, and professional practices tend to restrict who can be involved and how in the implementation of land management strategies. 
That said, collaboratively-informed implementation, as might be the case in the Dinkey Collaborative, is certainly better than no collaboration and provides a solid framework to build from. Collaborative trends in land management deliver opportunities for stakeholders to influence decision-making through involvement in the planning process and organizational coordination. However, these efforts are likely insufficient in delivering legitimate authority and responsibility for decision making and action to all collaborative participants, as agency participants must maintain their lines of authority and accountability.

At a more local scale, the SNF's partnership with the North Fork Mono and other tribal groups, within and without the Dinkey Collaborative, represents a positive trend towards greater collaboration between land management agencies and local stakeholders. And while we should not lose sight of the fact that the USFS is based on colonialism and capitalism, "inextricably entangled in and focused on profit" (Goode and Aldern 2015:41); it is, at its most basic level, an attempt to honor indigenous relationships to the land. Still, critical differences in the conceptions of what constitutes the "best available science" inevitably push the NFM and other local communities out of final restoration strategies. For instance, The Dinkey Collaborative Landscape Restoration Strategy states that a key goal of its restoration work is to provide current and future habitat for sensitive wildlife species such as the Pacific fisher and California spotted owl (USDA Forest Service 2010). These species require habitat that is apparently antithetical to the desired conditions of tribal groups like the NFM. This forest restoration strategy was established in the USFS Pacific Southwest Research Station's General Technical Report (North et al. 
2009) and guides management objectives on the Dinkey Landscape. It describes how fishers tend to inhabit oak trees that are densely packed with firs and cedars, and so it is ultimately this environmental state that many federal scientists and environmental advocates say must be protected. This is in contrast with Goode and other tribal members' assertions that the forest should be less dense and opened-up, restored, and maintained through periodic landscape burning.

Goode’s traditional knowledge informs him through narrative, history, experience, and direct observation that fire can restore cultural and biological infrastructure for himself and the fisher. Aided by prescribed burning, he argues, a healthy food web throughout the whole forest sustains these sensitive species. To sustain the fisher, we need to sustain its food supply; yet USFS scientists have revealed to him that they either know little about the fisher's food requirements or that they only concentrate on the requirements of fisher habitats (Aldern and Goode 2015). However, the Center for Biological Diversity's petition to list the fisher as a threatened or endangered species states that productive oak ecosystems, open orchards of mature, acorn-bearing black oaks that Goode strives for, “provide high quality food for fisher prey” (2008:8). Goode’s perspective, born out of generations of intimate relationships with the land in the region, focuses on food requirements, rather than habitat requirements. His and USFS biologists' perspectives are two parts of the same ecological picture, and should be understood as such in planning and implementation of restoration projects. Despite this, his perspective is systemically marginalized against agency scientists' despite its validity for informing and refining restoration strategies. 


\section{Future Research Directions}

Due to a limited sample size, any continuation or augmentation of it should include more in-depth interviews with disparate groups within the Dinkey Collaborative. Agency and tribal informants were invaluable for the information they provided, and while the agency and tribal perspectives detailed here may be commensurate with the thesis' narrow focus, they cannot apply more broadly to all stakeholder perspectives. Ultimately, the sample size may not have been commensurate with the scope of project objectives. At times, the research questions and objectives may have been too broad for one single collaborative. Instead, research questions should be targeted towards fine-grained, explicit points of tension or agreement within the Dinkey Collaborative; or, perhaps, towards larger questions that relate to many or all CFLRP projects.

Further, future studies of this type should be reinforced by an eco-archaeological component that links archaeological and ecological data to more reliably estimate the impact of Native American land management within historical ecological models. This, coupled with a greater awareness for the value of traditional ecological knowledge bases, provides local tribal communities a central function in collaborative restoration projects. This may, however, require adopting innovative, interdisciplinary approaches combining archaeological and anthropological research with relevant ecological, historical, and ethnographic sources of information. Fortunately, though, archaeologists have access to modern, innovative research on fire regimes, which is providing crucial information about fire histories, fire seasons, fuel sources, and the ecological impacts of fire on various biotic communities across the state, as well as methods for modeling natural 
(lightning ignition) fire regimes (Carle 2008; Sugihara et al. 2006). By combining the studies of archaeology, ecology, and paleoecology, researchers can pursue innovative eco-archaeological investigations that can generate information about fire histories, faunal and floral populations, vegetation conversions, and indigenous cultural practices that transcend prehistory and history (Lightfoot and Lopez 2013).

Such an investigation into Native American resource management is greatly facilitated by working closely with tribal members and scholars. These kinds of studies provide an approach that builds the foundations of long-term collaborative research programs with tribal groups, an issue of increasing importance in North American archaeology. It is no surprise that descendant communities are concerned with the state of their local environments and the health of culturally significant plant and animal resources. Therefore, these kinds of programs can be mutually beneficial for tribal groups to work with anthropologists in studies of landscape management practices, which may provide insights on restoration methods designed to enhance local biodiversity and the availability of traditional resources. Native collaborators can be critical partners in these eco-archaeological studies by supplying information about indigenous management drawn from their own daily activities and oral histories (Bird et al. 2005:449). In this way, tribal groups could benefit greatly in an area where they face continuous obstacles in perpetuating their cultural traditions. 


\section{REFERENCES CITED}

Aldern, Jared, and Ron Goode

2015 The Stories Hold Water: Learning and Burning in North Fork Mono Homelands. Decolonization: Indigeneity, Education \& Society 3(3):26-51.

Anderson, M. Kat

1992 Restoring Deer Grass. News from Native California 6(2):40.

1999 The Fire, Pruning, and Coppice Management of Temperate Ecosystems for

Basketry Materials by California Indian Tribes. Human Ecology 27(1):113.

2005 Tending the Wild: Native American Knowledge and the Management of

California's Natural Resources. Berkeley: University of California Press.

2006 Technical Note No.1: Traditional Ecological Knowledge: An Important Facet of Natural Resources Conservation. USDA-NRCS, National Plant Data Center.

Anderson, M. Kat, and Michael Barbour

2003 Simulated Indigenous Management: A New Model for Ecological Restoration in National Parks. Ecological Restoration 21(4):269-277.

Anderson, M. Kat, and Michael Moratto 1996 Native American Land-Use Practices and Ecological Impacts. In Sierra Nevada Ecosystem Project: Final Report to Congress Vol. 2. Pp. 187-206. Davis: University of California, Center for Water and Wildland Resources.

Ansell, Chris, and Allison Gash

2008 Collaborative Governance in Theory and Practice. Journal of Public

Administration Research and Theory. 18(4):543-571.

Bales, Roger C., John J. Battles, Yihsu Chen, Martha H. Conklin, Eric Holst, Kevin L.

O’Hara, Philip Saksa, and William Stewart

2011 Forests and Water in the Sierra Nevada: Sierra Nevada Watershed Ecosystem

Enhancement Project. Sierra Nevada Research Institute 11:1.

Bartlett, George

2012 Developing Collaboration and Cooperation. In North, M., ed. Managing Sierra Nevada Forests. Gen. Tech. Rep. PSW-GTR-237. Albany, CA: U.S. Department of Agriculture, Forest Service, Pacific Southwest Research Station: 81-88. Chapter 7.

Berkes, Fikret

1999 Sacred Ecology: Traditional Ecological Knowledge and Resource Management. Ann Arbor, MI: Taylor and Francis 
Berkes Fikret, Carl Folke, and Gadgil Madhav

1995 Traditional Ecological Knowledge, Biodiversity, Resilience and Sustainability. In Biodiversity Conservation: Problems and Policies. Pp 281-299. Perrings, C.A., Mahler K.G., Folke C., Holling C.S., Jansson B., eds. Dordrecht (The Netherlands): Kluwer Academic.

Bird, Douglas W., Rebecca Bliege Bird and Christopher H. Parker 2005 Aboriginal Burning Regimes and Hunting Strategies in Australia's Western Desert. Human Ecology 33:443-464.

Bixler, R. Patrick, and Brian Kittler 2015 Collaborative Forest Landscape Restoration: A Meta-Analysis of Existing Research. Pinchot Institute for Conservation.

Blackburn, Thomas, and M. Kat Anderson

1993 Before the Wilderness: Environmental Management by Native Californians. Ballena Press.

Browning, Peter

2011 Sierra Nevada Place Names: From Abbot to Zumwalt. Lafayette, CA: Great West Books.

Butler, William H., Ashley Monroe and Sarah McCaffrey 2015 Collaborative Implementation for Ecological Restoration on Public Lands: Implications for Legal Context, Accountability, and Adaptive Management. Environmental Management 55:564-577.

Carle, David 2008 California Natural History Guides: Introduction to Fire in California. Berkeley: University of California Press.

Center for Biological Diversity 2008 A Petition to List the Pacific Fisher (Martes Pennanti) as an Endangered or Threatened Species under the California Endangered Species Act. Retrieved from: http://www.biologicaldiversity.org/species/mammals/Pacific_fisher/pdfs/fisher-cesapetition.pdf.

Charnley, Susan, Melissa R. Poe, Alan A. Ager, Thomas A. Spies, Emily K. Pratt and Keith A. Olsen

2015 A Burning Problem: Social Dynamics of Disaster Risk Reduction through Wildfire Mitigation. Human Organization 74(4):329-340. 
Charnley, Susan, Courtney Carothers, Terre Satterfield, Arielle Levine, Melissa R. Poe, Kamma Norman, Jamie Donatuto, Sara Jo Breslow, Michael B. Masica, Phillip S. Levin, Xavier Basurto, Christina C. Hicks, Carlos Garcia-Quijano and Kevin St. Martin 2017 Evaluating the Best Available Social Science for Natural Resource Management Decision-Making. Environmental Science and Policy 73:80-88.

Codding, Brian F., and Doug W. Bird 2013 A Global Perspective on Traditional Burning in California. California Archaeology 5:1-10.

Cook, Sherburne F. 1976 The Conflict Between the California Indian and White Civilization. Berkeley and Los Angeles: University of California Press.

Cronon, William 1995 The Trouble with Wilderness; or Getting Back to the Wrong Nature. In Uncommon Ground; Toward Reinventing Nature. William Cronon, ed. Pp. 60-90. New York: W.W. Norton.

Cruikshank, Barbara 1999 The Will to Empower: Democratic Citizens and Other Subjects: Ithaca: Cornell University Press.

Deloria, Vine

1995 Red Earth, White Lies. New York: Harper and Row.

Deur, Douglas, and Nancy J. Turner 2005 Introduction: Reassessing Indigenous Resource Management, Reassessing the History of an Idea. In Keeping It Living: Traditions of Plant Use and Cultivation on the Northwest Coast of North America. Douglas Deur and Nancy J. Turner, eds. Pp. 3-34. Seattle: University of Washington Press.

DiCicco-Bloom, Barbara and Benjamin F. Crabtree 2006 The Qualitative Research Interview. Medical Education 40(4):314-321.

Downing, Jim 2015 Forest Thinning May Increase Water Yield from the Sierra Nevada. California Agriculture 69(1):10-11.

Ferguson, James 1994 The Anti-politics Machine. Minneapolis: University of Minnesota Press. 
Fernandez-Gimenez, Maria E.

2000 The Role of Mongolian Nomadic Pastoralists’ Ecological Knowledge in Rangeland Management. Ecological Applications 10:1318-1326.

Firehock, Karen E.

2011 The Community-Based Collaborative Movement in the United States. In Community-based Collaboration: Bridging Socio-ecological Research and Practice. Pp. 1-18. Dukes, E.F., Firehock, K.E., Birkhoff, J.E., eds. Charlottesville, VA: University of Virginia Press.

Fowler, Catherine S., Pauline Esteves, Grace Goad, Bill Helmer and Ken Watterson 2003 Caring for the Trees: Restoring Timbisha Shoshone Land Management Practices in Death Valley National Park. Ecological Restoration 21:302-306.

[GAO] Government Accountability Office

2015 Forest Restoration: Adjusting Agencies’ Information-Sharing Strategies Could Benefit Landscape-Scale Projects. GAO-15-298. United States Government Accountability Office: Washington, D.C.

Getches, David, Charles F. Wilkinson, Robert A. Williams Jr. and Matthew L. M. Fletcher

2011 Cases and Materials on Federal Indian Law. Aboriginal Policy Research Consortium International: Paper 213.

Gray, Barbara 1989 Collaborating. San Francisco, CA: Josses-Boss.

Heizer, Robert F.

1974 The Destruction of California Indians. Santa Barbara and Salt Lake City: Peregrine Smith.

Hernandez, Ian 2015 Tree Mortality in the Sierra National Forest. USFS News Release: December 14, 2015. Clovis, CA.

Hessburg, Paul F., and James K. Agee 2003 An Environmental Narrative of Inland Northwest United States Forests, 18002000. Forest Ecology and Management 178(1):23-59.

Hinton, L. 1994 Flutes of Fire: Essays on California Indian Languages. Berkeley, CA: Heyday Books. 
Hodder, Ian

2012 Entangled: An Archaeology of the Relationships between Humans and Things. Oxford: Wiley and Sons, Inc.

Hutchins, Emily G.

2015 Restoring Landscapes in the Context of Environmental Change-A Mental Models Analysis. Ph.D. Dissertation. The Ohio State University.

Kimmerer, Robin Wall

2002 Native Knowledge for Native Ecosystems. Journal of Forestry 98:4-9.

Kroeber, Alfred L.

1962 The Nature of Land-Holding Groups in Aboriginal California. University of Califonira Archaeological Survey Reports 36:19-58.

Kull, Christian A.

2004 The Isle of Fire: The Political Ecology of Landscape Burning in Madagascar. Chicago: University of Chicago Press.

Lee, Kai N.

2001 Appraising Adaptive Management: Biological Diversity: Balancing Interests Through Adaptive Collaborative Management 1-26.

Lewis, Henry T.

1993 Patterns of Indian Burning in California: Ecology and Ethnohistory. In Before the Wilderness: Environmental Management by Native Californians. Thomas C. Blackburn and M. Kat Anderson, eds. Pp. 55-116. Menlo Park: Ballena Press.

Lightfoot, Kent G., and Valentin Lopez

2013 The Study of Indigenous Management Practices in California: An Introduction.

California Archaeology 5(2):209-219.

Mann, Michael L., Enric Battlori, Max A. Moritz, Eric K. Waller, Peter Bereck, Alan L.

Flint, Lorraine E. Flint and Emmalee Dolfi

2016 Incorporating Anthropogenic Influences inot Fire Probability Models: Effects of Human Activity and Climate Change on Fire Activity in California. PLoS One 11(4):121.

Margerum, Richard D.

2011 Beyond Consensus: Improving Collaborative Planning and Management.

Cambridge, MA: The MIT Press. 
Mauro, Francesco, and Hardison, Preston D.

2000 Traditional Knowledge of Indigenous and Local Communities: International Debate and Policy initiatives. Ecological Applications 10:1263-1269.

Michel, Erica

2014 Up in Smoke. State Legislatures 40(5):26-29

Miller, Jay D., H.D. Safford, Michael Crimmins and A.E. Thode

2009 Quantitative Evidence for Increasing Forest Fire Severity in the Sierra Nevada and Southern Cascade Mountains, California and Nevada. Ecosystems. 12(1):16-32.

North, Malcom, with Peter Stine, Kevin O’Hara, William Zielinski and Scott Stephens 2009 An Ecosystem Management Strategy for Sierran Mixed Conifer Forests. USDA Forest Service General Technical Report PSWGTR-220:1-49.

Phillips, George H.

1993 Indians and Intruders in Central California, 1769-1849. Norman: Oklahoma University Press.

Radeloff, Volker C., with Roger B. Hammer and Susan I. Stewart 2005 The Wildland Urban Interface in the United States. Ecological Applications 15:799-805.

Rawls, James J.

1984 Indians of California: The Changing Image. Norman: University of Oklahoma Press.

Ribot, Jesse C.

1998 Theorizing Access: Forest Profits along Senegal's Charcoal Commodity Chain. Development and Change 29:307-341.

Richards, Rebecca, and Max Creasy 1996 Ethnic Diversity, Resource Values and Ecosystem Management: Matsutake Mushroom Harvesting in the Klamath Bioregion. Society and Natural Resources 9(4):359-374.

Rossier, Colleen R. and Frank Lake 2014 Indigenous Traditional Ecological Knowledge in Agroforestry. National Agroforestry Center. Agroforestry Notes 44(May 2014):1-8.

Running, Steven W. 2006 Is Global Warming Causing More, Larger Wildfires?. Science 313:927-928. 
Salmon, Enrique

1996 Decolonizing Our Voices. Winds of Change (summer):70-72.

Scarlett, Lynn

2013 Collaborative Adaptive Management: Challenges and Opportunities. Ecology and Society 18(3):26.

Schultz, Courtney A., with Theresa Jedd, and Ryan Beam 2012 The Collaborative Forest Landscape Restoration Program: A History and Overview of the First Projects. Journal of Forestry 110(7):381-391.

Smith, George A.

2004 The Role of Indian Tribes in the Section 106 National Historic Preservation Act Review Process. SJ053 ALI_ABA 649.

Spier, Robert F.G.

1978 Monache. In California. Ed. Robert F. Heizer. Pp. 426-437. Volume 8 of the Handbook of North American Indians. Washington, D.C.: Smithsonian Insitution.

Sugihara, Neil G., with Jan W. van Wagtendonk, Kevin E. Shaffer, Joann Fites-Kaufman and Andrea E. Thode

2006 Fires in California’s Ecosystems. Berkeley: University of California Press.

Stewart, Omer C.

2002 Forgotten Fires: Native Americans and the Transient Wilderness. H.T. Lewis and M.K. Anderson, eds. University of Oklahoma Press: Norman.

Syphard, Alexander D., Volker C Radeloff and John E. Keeley 2007 Human Influence on California Fire Regimes. Ecological Applications 17(5):1388-1402.

Tongco, Ma. Dolores C. 2007 Purposive Sampling as a Tool for Informant Selection. Ethnobotany Research and Applications 5:147-158.

Turner, Nancy J., and Sandra L. Peacock 2005 Solving the Perennial Paradox: Ethnobotanical Evidence for Plant Resource Management on the Northwest Coast. In Keeping It Living: Traditions of Plant Use and Cultivation on the Northwest Coast of North America. Douglas Deur and Nancy J. Turner, eds. Pp. 101-150. Seattle: University of Washington Press.

[UNEP] United Nations Environment Programme 1998 Report of the Fourth Meeting of the Parties to the Convention on Biodiversity. Nairobi (Kenya): United Nations Environment Programme. UNEP/CBD/COP/ 4/27. 
USDA Forest Service

2010 Dinkey Collaborative Landscape Restoration Strategy. Dinkey Collaborative Group: Clovis, CA.

2014 US Forest Resource Facts and Historical Trends. FS-1035. Washington, D.C. 2016 Forest Service Research and Development: Tribal Engagement Roadmap

Highlights Report. FS-1075. Washington, D.C..

Vale, Thomas R.

1998 The Myth of the Humanized Landscape: An Example from Yosemite National Park. Natural Areas Journal 18:231-236.

2002 Fire, Native Peoples, and the Natural Landscape. Island Press: Washington, D.C. 


\title{
Appendix A: Consent Form
}

\section{REQUEST FOR YOUR PARTICIPATION IN RESEARCH}

\section{TITLE OF STUDY}

Traditional Ecological Knowledge in the Sierra Nevada

\author{
NAME OF RESEARCHER \\ Michael Boero (Graduate Student), San Jose State University
}

\section{PURPOSE}

You have been asked to participate in a research study indented to document traditional ecological knowledge in the Sierra Nevada. The goal of this research is to record personal stories about historical and contemporary ecological management in order better understand past, present, and future land management in the Sierra Nevada.

\section{PROCEDURES}

You will be asked about your own stories, experiences, and thoughts about the integration of traditional ecological knowledge into land management and general questions relating to your thoughts on historical and contemporary land management. These interviews will be used to document the integration of traditional ecological knowledge into forest management in order to better understand past, present, and future Sierra Nevada landscapes.

The researcher would like your permission to record this interview, which will be transcribed (a copy of the transcription will be given to you for your records).

Please check this box if I have permission to audio record this conversation:

\section{POTENTIAL RISKS}

The risks of participation are no greater than risk experienced in daily life. However, participants may experience a loss of privacy. All participants may self-edit their interview content, even after completion of the interview. Any and all publications will be made in good faith to respect the cultural or religious information of informants. To this end, publications specifically concerning cultural or religious information will be sent to the participant for review prior to publication. This step will hopefully help avoid the dissemination of sensitive, inaccurate, or misleading information.

\section{POTENTIAL BENEFITS}

It is the goal of this project to add multivocality to ecological and environmental narratives of the Sierra Nevada. In this way, the study has the potential to emphasize contributions towards reducing wildfire and drought risk, increasing biodiversity, and enhancing vital cultural connections and traditions among local Native American groups. Further, I hope to aid in the preservation of traditional ecological knowledge in order to further support multiple perspectives in contemporary and future land management decisions.

\section{CONFIDENTIALITY}

Because your personal connection to the land is important for this study, basic identifying information will be reported. Your name may be included in the interview transcripts and 
publications, unless otherwise requested. In the event that you would like to have your name removed from the study, identifying information will be collected, but not reported. Please indicate below if you would like your name removed from the study.

Please check this box if I do not have permission to use your name in this study:

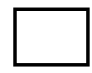

\section{PARTICIPANT RIGHTS}

Your participation in this study is completely voluntary. You can refuse to participate in the entire study or any part of the study without any negative effect on your relations with San Jose State University. You also have the right to skip any question you do not wish to answer. This consent form is not a contract. It is a written explanation of what will happen during the study if you decide to participate. You will not waive any rights if you choose not to participate, and there is no penalty for stopping your participation in the study.

\section{QUESTIONS OR PROBLEMS}

- $\quad$ For further information about the study, please contact Michael Boero at (925) 8997131 or mpboero@gmail.com.

- $\quad$ Complaints about the research may be presented to Roberto Gonzalez, Anthropology Department, San Jose State University, at (408-924-5715) or Roberto.Gonzalez@sjsu.edu.

- $\quad$ For questions about participants' rights or if you feel you have been harmed in any way by your participation in this study, please contact Dr. Pamela Stacks, Associate Vice President of the Office of Research, San Jose State University, at 408-924-2479.

\section{SIGNATURES}

Your signature indicates that you voluntarily agree to be a part of the study, that the details of the study have been explained to you, that you have been given time to read this document, and that your questions have been answered. You will receive a copy of this consent form for your records.

Participant's Name (printed)

Participant's Signature Date

I certify that the participant has been given adequate time to learn about the study and ask questions. It is my opinion that the participant understands his/her rights and the purpose, risks, benefits, and procedures of the research and has voluntarily agreed to participate. 


\section{Appendix B: Interview Questions}

\section{Traditional Ecological Knowledge in the Sierra Nevada Michael Boero \\ Interview Questions}

How do you define traditional ecological knowledge (TEK)?

What are the benefits of integrating TEK into forest management?

Are there differences between tribal or traditional science and Western science as it relates to forest management?

Are there any obstacles towards integrating TEK into forest management?

Can you describe the role of fire in your life?

In your view, what are some different kinds of fire (e.g. wildfire, prescribed fire, cultural fire)?

Is there a difference between 'good' and 'bad' fire?

How would you describe the current environmental state of Sierra Nevada forests?

What are some historical events that have positively or negatively affected or determined the current environmental state of Sierra Nevada forests?

How have Sierra Nevada forests changed over your lifetime?

How has tribal collaboration with land management agencies and/or academic researchers changed over the years?

What role did Native Americans have in shaping the historic Sierra Nevada landscapes that Euro-Americans encountered when they first arrived? Is this role appreciated today? 


\section{Appendix C: Semi-structured Interview with North Fork Mono Tribal Chairman Ron Goode}

[Recording starts]

Ron Goode: ...they're talking about, they have to have dense cover, but the moment the forest in the Dinkey project is thinned - take Blue Canyon, for instance - they thinned in a couple areas, and as soon as they thin, here comes the fisher, you know. And the first comment, or questions, from the fisher people is 'Why, I don't understand why they're over there". What do you mean you don't understand? There's food over there. You've opened it up.

Mike Boero: Kind of going back to their prey?

RG: Yeah. Of course they're over there. [laughs]. You know? It's like they think that they're only going to stay hidden.

MB: So is it just their recent science that suggests to them that a denser forest is more favorable? Is that going back to what you were talking about where, to think about today more than the past?

RG: We're slowly making that change a little bit. They've seen what happens in wildfire. It's kind of hard for them to say "Well, we did good by protecting the fisher..." We have an owl story that's the same as the fisher-the spotted owl. This one was a great grey owl. We were overlooking Mammoth Pool, the Mile High Lookout, with the Forest Service and others and we left from there and we were looking at the Aspen Fire and down on the south side of the San Joaquin River. Then we got down to the next stop, Mile High Campground, and one of my members had a picture of him in a baby basket propped-up against one of the trees. So we can clearly see what it looked like back in the 1950s, how open it was. And we were, ya know, the conifers were probably 200 years old and the oaks pushing 3-400 and the question that came up to the Ranger was "Well what happens if the Aspen Fire would've jumped the river?" He said "It would've came right up that draw right there and it would've wiped all this out". So I turned around and I said "You have a density here. You say there's an owl pack here. So this density, it's 25 years old. Why?" This was 2014, he said "Well, because in 1991 the owl hooters heard an owl hoot here. Heard an owl hooting." So now it became an owlcore, and they left all the brush-young, second story growth - to grow, 25 years of growth. And I was right on target when I said "This undergrowth is 25 years old." and he said "Yeah, because we heard an owl hoot here". Well, I said, I'm an archaeologist, I know for a fact that owl doesn't live for hundreds of years, but if an owl is continually coming back to an area and this is his nest, then how old is his nest?" He said "He don't have a nest, we just heard him hoot here". [laughs] And for that you made that? You drew a circle on a map and said "Leave this area alone"? 200 year old conifers and 3-400 year old oaks and you want to destroy it. "Well, we're not trying to destroy it, we're trying to protect the owl". I says, "Yea, and the man just got done telling you that the Aspen Fire would have destroyed it, ya know?" "Well, ya know, this is our policy". I says, "Oh, OK. So when a fire does come through here, what's going to happen?" "Well, the owl doesn't have a nest here so he won't be here" Oh, lordy! Very good, because now you left a density to let the conifers to get burned up, the oaks to be burned up. Because otherwise they would be open enough that a fire would burn through them. But now they can't. That same summer, because we were there early, in June or so, then came the French Fire- the French fire took everything out.

\section{MB: That same area? Same spot?}

RG: Same area. All them beautiful 200 year old conifers, and oaks, all gone.Ya know, maybe the fire was burning so hot it would've burned the crown out anyways in the first place, but the bottom line is it definitely was going when it hit the understory. There was no other chance, in other words. And this is your policy. [laughs] So then we were like "OK, well here's what happened"-I think what was Richard Duvall told them in a meeting one day-"Here's what happens. When you burn em out and the trees grow back- 
his nephew or his cousin, or somebody's going to come back and live there again, with or without your understory. Do you not understand this? And yet, what did you do? Because you did this." He tried to tell them, "You did that, you put that understory there." You know? And that's what you're doing with the fisher. Same thing you're doing with the owl. Wow. We had the Whiskey Ridge Ecological Project. One third of it was immediately marked for fisher and owl. And all for potential spots. Not even anybody there.

MB: They hadn't even heard an owl?

RG: No! [laughs]

MB: Potential?

RG: Potential. Immediately they were all [?????]. Ridiculous. There's no policy that covers that. None. So that's what the Dinkey Collaborative and other collaboratives are all about...is, yea, everyone has the right to come in and, ya know, expound on their agenda, but you've got to be able to see the whole picture. And that's what took us 5 years-I guess we're going on our 6th year now-and it's getting very hard for all of them to see the whole picture.

MB: Do you think certain perspectives in this collaborative are given more weight?

RG: In the beginning, yes. In the beginning, a lot. It's what chased a lot of people off at first. Where do you get your voice at? And i guess to a degree that's why they got the charter going that says that everybody has an equal right to vote on something when it comes down to it. But there's so much information to run through that it's hard to decipher it all. Even research. Research is something that's done, and then we have to see-play it out, years- to see if this is true or not. Because people's research is based on basically what they see in front of them. They're not doing research on hundreds of years of observation and knowledge. And so, yet, since they're smart and they know how to word things and they put all the text in there. I don't know if you've been following the latest water debacle, for the new legislation...they're trying to put legislation through that we have a national water bill for specific projects. Then they're trying to tag this new California thing on for infrastructure here that everybody's fighting. And there's a lot of other stuff in it and they couldn't-I forgot how many hundreds of pages it is - a lot of it technical jargon that nobody can understand. They come out with lots of stuff you have to read through it, read through it, like what are they saying? What are they saying? Do they understand what they're saying?

MB: Makes your brain numb, you can't even understand what they're talking about

RG: Yea, I read and then I put it away, and then I come back and I'll read it again. And then i finally pick something out and chew on it for awhile, see if I can figure things out. Good stuff, though, will pop right out. But what I call good is probably something that compounds with what I'm thinking [laughs]. You got any other questions?

MB: Yea, just some basic ones we're already kind of covering. But what I was interested in, you kind of hit on it earlier, about there being planning, and then implementation, and then it goes to the monitoring stage. How it's all supposed to be collaborative. But maybe it doesn't always work out like that.

RG: Well, ya know, the thing about monitoring now, we have a new monitor, just as we have a new archaeologist, they're hiring everybody from back east who have no knowledge about what's going on out here. The monitor is hired out of college. No experience whatsoever, except for even like yourself, I shouldn't say you don't have any experience-you've been out in the field a little but — but no real record coming in and we got in trouble in the Dinkey in our monitoring process of looking at the thinning projects, for one. And one thing they did good was their lidar and their satellite pictures, because of the heavy 
crowns in the tall conifers, even through they thinned, they only thinned smaller trees, and so therefore they never opened-up the higher-level crown which is also important because when it snows, or when it rains, where does that sit?

\section{MB: [Points up]}

RG: Up on top, exactly. Another thing was that they went out and counted trees per acre. And so they come up with....the first time they had 26 trees per acre. The second year they came out with 10. Like, "Woah, what happened?" "We don't know. We had a different crew." "You didn't train them the same?" "Probably not." They can't count the same?! Then, like I told them, the other thing is when you can, what's their spatial? From my experience, 10 trees on one acre, that's a little much. Spread out? It could be alright, depending on how big they were. If they're huge, not so good. Smaller, OK. That information wasn't given. What kind of monitoring are you doing? So, I tried to tell them "Well, OK, a tree..." because they measure everything 2 feet and under, "what about the big ones, what about the bigger ones?" "Well, they didn't measure bigger ones. They measured little ones." OK, so those that are 12 inches are probably 40-60 years old, those are 20-24 inches they're probably 150 years old. Well it turns out I was little bit light, but I was kind of, my high was actually the bottom end. So, then, I still didn't quite agree, but that's alright. But, OK, there you are. Trying to tell them how long these trees have been out here. To them it's just "Let's call it monitoring" But, that's what's been going on. I have a monitoring project we did over in our area where we measured everything and get our sizes, came up with our oaks, pretty much the bottom line was that we had plenty of big oaks and plenty of little oaks and lots and lots of babies. Which means we got acorn somewhere [laughs]. We haven't found it, but there's gotta be acorn if you've got hundreds of big leaves coming in. But in the meantime, we had just a smattering of mid-size trees. So there was a period of time in which we lost that grove. That grove didn't exist, and that's your prime, because the old aged ones, they're not producing anymore. There's cavities, and yea, they're habitat, true. But they're not producing food. It's highly important that they have to be producing food. But with fact that you have a hundred little seedlings on the floor, somebody's producing acorn, I don't know who, which tree, but we got some. This is good. Meanwhile, back to the Dinkey monitoring, "Well, how many seedlings do you have?" "Oh, a bunch." [laughs] "Hello? Give me an estimate." "Well, we didn't really do that." "What are you doing?" And that's really the essence of the whole thing: monitoring. Well, what are you monitoring? Who told you to go do what for monitoring? I'm always asking these questions, "What's the agenda here? Somebody's got an agenda? Somebody's got an agenda to say what they want out here in the Dinkey? That means the Forest. Somebody on the Forest is looking for something and they're directing how to go about doing it. So that's where it comes down to, it still comes back down to, the Forest is utilizing the collaborative, utilizing from the collaborative money to take care of they want, not what the collaborative wants.

MB: In the end, they need to meet their own goals?

RG: Yea. Then, too, as Native Americans, those of us that are there, we're all volunteers. I'm not getting paid. I don't get paid. And those that are there are getting paid. They're not getting paid to do this. But then when we looked at the budgets that were coming out, and you see that the fire person is being supplemented 37,000 a year, I don't know how much more they make, but that's pretty much their whole salary everyone. And it's not just one, there's a whole list of them. Every time they go out, they charge the collaborative. Well, what about us that are out here for the goodness of our heart, we don't get nothing. We got to buy our own lunch and everything else, except for when we're at a meeting [laughs]. Then all the rest of these guys are all getting paid? Paid to be here, paid to go out in the field? Paid to do their work? That's what the collaborative, that Obama signed, was to put people to work. Well, ain't nobody working. Nobody's being put to work. The money's all being used for people that are already working. Well, I know that their budgets have all been cut, but that isn't the design of what this financial funding is for. Maybe some of it, for those that are going to go out there in the field, then maybe they should be paid, when they 
do that particular job for the Dinkey. But not part of their salary. When you see that it becomes really disheartening. What the hell am I doing? What are we doing here?

MB: Yea. Frustrating.

RG: Yea, what are we doing here? [laughs] And then I asked them about meadows. Because they call part of it meadow restoration. We've been out to look at meadows and designated some. There's no plans to do anything.

MB: Not as part of Dinkey. Where was the meadow restoration that I had...

RG: All mine is on the other side.

MB: Bass Lake?

RG: Yea.

[00:21:57]

MB: You had also told a story about how there was a fire manager, you had talked about the difference between burning for resources? Like cultural burning might bbe more for burning for resources, whereas the Forest service tends to maybe burn for acres? Are they thinking that just putting fire on thelandscape is good enough, but they're not thinking about what kind of fire?

RG: Not necessarily. The reason they put fire on the land is to be paid for it. That's it. The more fire they put on the land, the more they get paid. The more acreage they burn, the better they get. That's it. That's the bottom line. There's no...

MB: That's all it is?

RG: That's all it is. Then, take that out of the equation. Now why are you burning? "Well, because we're going to try to improve the landscape, we're going to be thinning, we're going to be improving the landscape." So, I've been trying-I just wrote a new protocol, or whatever you want to call it—and it hasn't been discussed or cussed, probably been used for toilet paper by now, but I have a contract that says I can burn on the forest. We have liability, we've been burning all of our lives. I've trained all my young people. So, we've said, when we brush, we brush our piles all throughout the meadows and on the edges of the meadows, so we can then burn them. They're small, little beaver hut-sized pile, you've seen them. And the idea is that actually when you're being you can from one pile to the next, or you can burn several of them at once. And when you get done you can fix your ash piles and winter comes or whatever and you've got water, you're good. And then it grows back nice and lush. They wouldn't let us burn our piles, so last year on the North Fork side, one of the gals took her crew out there and she burned 50 of our piles, but never finished them. So, June came and we went out, and she was all proud of her burning, and the first thing my nephews all said was "We couldn't see where you burnt. It should be all lush vegetation. Flowers and plants, and food plants and medicine. Everything that grows out here should be growing right there. Not your ash pile, it shouldn't still be there." "Oh! Well, we didn't know how to do that." You didn't call us either, did you? You didn't ask us to come out here to help you, share with you, teach you. No, you just did it. And now you've screwed it up. So new we've got to rake it up and hopefully this coming winter everything will grow back. Right? That's our hope. 
MB: Maybe that's the problem with "Sure we can collaboratively plan what we're going to do" but when they're actually going to do it they don't let you help, or do it.

RG: Yea, so the guy on the High Sierra side, he also tried that. He went out and burned 780 acres under the oaks. he told Jared [Aldern], "Oh I read Ron Goode's cultural burning articles, I'm good to go." So, yea, he burned up all the oaks, a couple - two, three — are gone. Like Jared said, "Well, even that, we've got new leaves coming back on the oaks." Even though you screwed up, it's better than nothing. But look what you did to the base of the tree.And why? Because they don't prep. No preparation. You can't take a weedeater and go out there and cut around the oaks? When you're gonna burn that's what you do. You go out and clear the ground. Then you burn. And everything that comes off the old limbs and what you rake up that you burn in the piles underneath the oaks so it gets good smoke, some heat, and then you broadcast burn around it and it don't burn under the oak. But no, they can't do that. And the burn lady that was out there, she did it, 7, 8 in Providence, she killed 12-15 oaks. They're not coming back. "They burned hotter than I thought". Yet, I see flames 60, 70 feet up the conifers. [laughs] You didn't trim around nothing? You only got 8 acres. You can't take a crew of people to go out there and do prep work? "No, we don't do prep work". Oh, where have you been burning all your life? Who taught you how to burn?

MB: Do you think it's a lack of knowledge or that they don't want to?

RG: I think it's a little bit of everything. Because they tell me they've been trained by the lady who's the head chief, ya now, "Oh, I was trained by one of the old Indian guys". Really? You missed a class someplace. [laughs] Oh, I don't know. It's just the frustration. I'll go again tomorrow to see what's going on. I've worked with them, I've helped them. I'm on the Fire Work group and we tried last November going down to see the air pollution team. And we tried to get the air pollution people on board with a number of things, we had quite a list - too long for our presentation when we went down there. But, the thing was is that - a couple of things that we really zeroed in on, that would make a difference-and that was they call the window. When they get a window to burn, this a good burn time, they give you a couple-2 or 3 days. So by the 3rd day the window is closed. "Oh, we need to shut your fire down now", and yet they've got another 2 or 3 days left of burning. So now they shut it down and it's going to take them 2 or 3 days, and then it's going to be all stinky and bad instead of letting them burn through. So that was what we were pushing for. When you give them a window, keep it open, no matter what, let them finish that project, then that's done and you've got a big 400, 500 acre piece, 600 acre piece done. Right? "Oh yeah, OK. Well..." They were being pretty stubborn and din't really want to lift it, but the staff was helping us. They could see that we need to do something, especially after the Rough Fire came and ash fell like a snow down here in the valley. "OK, OK, OK. We do have to do something". So I told the Sierra Forest when we were doing this in November, "OK, plan a project in its entirety, have it ready to go". "oh, they're not going to make a decision. We won't be able to do anything until 2017. We've got 2 or 3 meetings set-up with them between now and January, February", this was way back in December, "2 or 3 meetings then summer time will come and then maybe the next year they'll make a decision". You don't know that, this is what we're doing right now. It's needed now. So get your project for next year, have it ready to go. Well, they didn't. And all of a sudden in April, the air pollution people just woke up one day and came to work and said "OK, here's the things we're going to change and we're going to make the changes right now, and right now one of them is when we open up the window we're going to leave it open. And you've got to tell...", this is mid-April, "and you've got until June 1st, so have it!" Our Forest didn't even try. They weren't even ready. But Sequoia did, Sequoia jumped on it and got a 750 acre burn right then and then. Took them 7 days to burn it, and boom! They were done.

MB: Is that because they had something ready?

RG: Yea, they were ready.They swooped down and did it.Then ours is still not ready. And that's another frustration with the whole thing. After all this, and you're getting paid by Dinkey to do this. And then you can't even get ready. 
MB: Yeah, what is all this for?

RG: They've got all kinds of excuses why. But, that's just excuses.

MB: How often are these meetings, these Collaborative meetings?

RG: Sometimes monthly, sometimes every other month. They come and go. This was suppose to be one in November, and then they changed it to December. I haven't been since like June, or something. [laughs] Because I was out with my surgery, getting prepared for that in July. I'm still not really ready to go sit all day long. In fact I don't think I'm going to make it til about 2:30 or 3 anyways.

MB: Do you think the Collaborative is getting better? When did it start? 2010? Do you think it's getting more productive?

RG: I think we're about done. That's what I think. They're trying for more funding. Sierra Legacy, which has 7 or 6 organizations, including Sierra Club apart of them, supposedly left, they still show up occasionally, but they said they're out. The wilderness people that was running, Stan, he was running the ?group?, he's out, they left.

MB: Why are all these people leaving?

RG: Because they don't think that the Dinkey is, it's no longer productive for what they need and so therefore their interests, Legacy's interests is in fire, more fire on the land, so they're going to go back to probably suing and trying to legislate things to push for more fire. The wilderness people, they really need to be a part of that new plan within the region, they want more wilderness up there. And most of the tribes are all fighting it. They've already called me a couple times, "Can you explain why more on why you guys don't want more wilderness?" Because you guys have the perception about wilderness, you think that, and it even says it right there in the plan, you don't do anything to it, you don't touch it, and you have no plans to do anything with it, so it won't cost you anything. And that's what it's all about. So, you just leave this land sick. No, that's not the way it was, that's not how you found it. We were able to go through here, and it was beautiful, you could still look at the meadows, and you call it pristine. These things were all in place and we took care of them, it was where we lived. Trails that go through, you still following our trails. They don't seem to get it.

MB: It seems there's this hurdle that some people can't get over, about the perception of wilderness, and it even says in the 1964 Wilderness Act, "Land to be set aside as untrammeled by man"

RG: Yea, I know. That whole concept has to be changed. The park people over there on the other side, but I'm doing a lot of work with Sequoia-Kings Canyon [National Park], and they're telling me that administratively and arbitrarily, those that are in charge are dealing with it differently to a degree. And not following the letter of the policy, but what is needed. And they're still not able to actually go out there and treat it the way they need to. But, that's just them, here the Yosemite people are completely indifferent. Of course, they've hired Kings Canyon supervisors now, finally fired theirs. So maybe there will be a change in Yosemite, as well. But back to the Forest with the wilderness, they're not willing to change from whatever that Act says, because it complies with how they view their financial attack. It's not about taking care of their land, but that's what they're supposed to be doing, you're supposed to be stewards of the land.

[00:38:39] 
MB: Is Sequoia-Kings Canyon typically better at managing that way than Yosemite?

Rg: They seem to be a whole lot better. It has to come from administrative in the sense that somebody's willing enough to be relaxed enough to say "let's deal with this". I just went to a symposium, 2 day symposium, of all their researchers and all outside researchers who come there to work, that's where they do their stuff. I forgot how many of them there were, lots, 2 days of speakers. Wow, this is the kind of effort-millions of dollars have been pout into the research program. Wow, OK, all good stuff, but, at least if you're going to go that far... We've got a good case in point: The Dinkey Collaborative, the [UC] Merced University, Roger Bales has done a study in provenance, about the water shed. It's never been presented to the Dinkey Collaborative. I heard about it down at Tulare Watershed meeting. Good report, I disagreed with some of his work, but it's still a good report. But it was based on his study in provenance for the Dinkey Collaborative, and yet his report has never been given to the Dinkey, from over 2 years ago.

MB: Why is that? Is Dinkey just...

RG: That's just how I, the difference that I'm looking at. Here are a number of outside people doing studies here, and we don't see their reports. We don't see what their doing. Where as over there, on the other side, on the KingsRiver, KIng's Canyon, man they invite their people to come in there and talk, and then they tell me, the land manager's tell me, "Oh yeah, we have people come into our particular small groups and do sessions. Our own people too." Now in the Dinkey, we've got a few people that give reports, but I don't consider them-just land managers, that's all I consider them. I don't even consider them good practitioners. Sorry. I lost a lot of confidence in what they do and who they are and what they say they're doing.

MB: From the perspective that I come from, archaeology or the cultural side, I remember working with some of the fisher people up there at Pacific Southwest Research, even talking to some of these people who are Forest Service ecologists, and they just, I don't know, they just focus too solely on one thing and don't think about the whole picture - today and in the past, and how it all connects together. And I can feel like, I don't klnow if its a Forest Service thing, but maybe it's just the way they teach ecology nowadays or something. Seems like they're missing a big part.

RG: Well, like I said, too, there's like 10 million dollars given to the fisher study, and there's been a big busy study over there in the Cedar Valley on the North Fork side. I know they've done a little bit of presentation, but there hasn't really been any major, every year presentation on what they're doing. Now, they're outside of the DInkey, but still Forest money. It's still grant money that's come in and that fisher, the males from that fisher pack probably even wandered over here because that's less than 40 mils, so I don't know how far they go, but ya know? We should kind of know what they're doing over there and how their study's coming out compared to how these guys study is coming out.

MB: With all that money, I hope so.

RG: Yeah, I know. But that hasn't happened. When you start talking money, you start talking...it's kind of like home. It's what breaks up families at home eventually: finances, the money. Either lying or not being up front with what you're dong with their money, or how their money is being spent.

MB: Or they don't want to justify where they made their money...

RG: Or they don't want to justify things. Like, "OK, this is not good, right?"

MB: "Sorry for asking!" 
TG: Yeah, well that's exactly where we are with the Dinkey Collaborative. They'll give you a report and then you got to read between the lines yourself, try to figure things out.

MB: Yea, that's interesting.

RG: You know a lot of the things we'd like to see get done and do in restoration work, we've had none of that. So, I don't know. I know that Cold Springs is trying to make a move politically, in a sense, to put projects out there that they want to see get done that they want to be involved in. It's all good, but at the same time, it's not going to happen. They'll come out and appease them, they'll go out there on trips with them because this is what they've done with us. We've gone out to see meadows, we've gone out to see oaks, and then the new fire man there in the Dinkey, he went out and burned one of those plots that we said needed burning, but never invited any of us. And afterwards, "Oh I burned and it didn't quite come out so good".

MB: Kind of just giving you lip service.

RG: What the hell? You know? Are you just out to play? What's the point here, there's absolutely no point at all what you just did if you're not going to work with us. Maybe you forgot something, or...I don't know what it is, I can't put my finger on it. Like I said before, when I was out at Meserve [Meadow], same guy, and I said "Well, what do you guys do?" He says "I can see that what you do is restoration work", and I said "Duh, yeah, you know, I mean that's exactly waht I've been saying for hoe many years. this is waht we do. What do you do?", "Well, we maintenance things". "Well, what is maintenance?" "Well it's supposed to be restoration." Supposed to be restoration. Somehow or another it doesn't get maintenance, doesn't get the restoration when you guys do it. Why is that? "Well, I don't know." "But you're the gone in charge, you're the one doing it, what do you mean you don't know?" And that's the disconnect.

MB: What are you maintaining if you don't restore it first?

RG: Yea, or either way, if you're going to maintain it you should be restoring it, that's the point. I guess, kind of like a car, you keep changing the oil, but you got a bad head gasket...[indecipherable]...you got to change the head gasket.

MB: Yea, maintenance isn't going to do anything for it.

RG: No, once you got everything fixed, then maintenance is OK. But first you got to restore it. Like you said, you got to restore that sucker.

MB: But if you're going to maintain and that's all you're asked to do, then...

RG: I guess, it always seems to come back to the financial aspect of things. And then it's not enough. Not enough so therefore they try to hide it. Not literally try to hide it, but it's like we don't talk about it, it just stays hidden. You know, like a hidden agenda, that's what I come back to all the time, "What's the agenda here, man? Who's got what going on here?" We all seem to be not on the same page. So, you go, and I try to go with an open mind and see what it is they're doing or what they're up to and then next thing I know, ah, man! I've been here for how many years? Coming to how many meetings? Where have we gotten? WE've gotten nowhere.

MB: And the same issues come up? 
RG: Yea, nothing's being really done. So, I don't know. Then they come in with other studies from 24 other collaboratives, "You guys on the Sierra, man you guys are the best, and everybody in the whole United States just thinks so much of what you guys are doing!" And I'm going oh, no! This is pretty bad!

MB: I kind of got that feeling, too, that the Dinkey was the poster boy for some of these projects, so I was going to ask how it compares to some of the other ones...

RG: Yeah, oh man! It's terrible [laughs]. You guys are doing a terrible job! It's terrible. If this is what they're doing, what a waste of money.

MB: Maybe it's just a matter of them patting themselves on the back. Like they're doing there...

RG: Maybe, because I haven't heard of the other ones, this is just something that comes back to us. Anyway, but that would be a thing for you, get a list from Washington or wherever, Congress or something, say :"Hey I'm doing a study, give me a list of who these contacts are, I'd like to find out what they're doing, what they think of what the Sierra is doing."

MB: Yea, people who are higher up?

RG: Yea

MB: That would be interesting. I mean, I started focusing on these collaboratives that started in 2009, they started these collaborative forest landscape projects, like Dinkey, and was kind of wondering where they were at, and we've got a new president coming in...politically, what of these sort of things are going to keep going, as much as they can show that they are productive...

RG: I don't think so, I don;'t think so, but I could be wrong. I don't like the guys, but I'm still always open enough, but for how he talks, he don't believe in the Forest, he don't believe in all these science things, unless he gets some people around him that does. He's a money man and this country is built on goods and services. That's what the Forest is all about: goods and services. It's gotten to the point where it's not, but that's only by timber. But now what it is is recreation. And the case in point was as Dean Gould [Forest Supervisor] tried to talk me down about it one time, it just recently came back down again from Randy Moore [Regional Supervisor] up in Region 5, he's thrown this email out before that 150 million was made from timber in Region 5, but 9.2 billion was made from water.

[00:51:19]

MB: Water?

RG: Water-related activities.

MB: Including recreation?

RG: Oh yeah, everything. Everything gets tied to water, and everything is tied to water. So then water became a commodity. I'm on the state water board, Native American advisory. I wrote an article which barely came out in the last water plan, it's supposed to be attacked again, but I was too heavy for them, and they couldn't deal with it. The bottom line is when they first gave it to me, and they went through 5 other authors before they came back to me. But, the thing was is cultural dependent resources-I've got the 
article, I can give it you — but, I explained to them culturally dependent resources and what that means. Then they ask me in the last paragraph, "Well, but you also have to do other water resources" "Like what?" "Like surfing, skiing, boating, fishing". "That's recreation!" "Well, they're culturally related resources." "That ain't cultural! Maybe to your culture someplace." [laughs] That's commodity. It's hard to explain, you know? The Indians have always had a commodity, but we don't treat it as a commodity. There's always commodity, because there's always trade and there's a value to everything, but not this kind of value. Not worried about money_dollars and cents. And that's where they got stuck. And I even tried to write something for them, about a half a page without blowing it up and being ugly with them over it.

[00:53:41]

MB: Trying to hold back a little bit?

RG: Well when Randy came out with that, it was like, "Exactly, you just made my case in point". 150 million on timber and 9.2 billion on water? Yeah, How'd you come up with that, by the way? I can see your timber one was easy, how'd you come up with the water one?

MB: Yea, how do you come up with that?

RG: Yea, how do you come up with a value like that?

MB: You said 9.2 billion?

RG: Billion.

MB: Wow.

RG: So, you know, that immediately puts water as a commodity. It just goes back around, it ties in with the Dinkey Collaborative, all collaboratives, they all tie in to this whole concept, when you talk about this president, that's what he is, he's a commodity man. He says he knows how to make money, he probably does. He also doesn't [indecipherable] it. Many of his corporations have gone broke, bankrupt, but like a good billionaire he pulls them back out or starts something else and just keeps going. I've been around rich people, rich-minded people, the concept is, throw it up against the wall, what sticks sticks. Don't worry about what falls off. That's a tough way to think. Not my way of thinking. I'm concerned about [?small little costs?]. Doesn't even bother to expose to anybody what it is he does, or how he makes it. But, how else is he going to, I say teach, how else is he going to practice what he, ya know, when it come back here to us, locally. I fear for the fact that he's going to fall right into the hands of all these people that want another dam on the San Joaquin for farmers. It's not for farmers at all. It's for urban development.

MB: But they say it's for farmers...

RG: Oh yeah, because that's how you're gonna get it, saying it's for farmers. There are farmers right now who aren't a part of irrigation districts—-they don't get no water. They just drill.

MB: They have their own aquifer, or...

RG: Yea, they don't get the dam water, they get it drilled down to find their own hold.

MB: But our political representatives are more than happy to fight for them on their behalf. 
RG: Oh yeah. That's what this fight right now that's going on with this water issue, is Barbara Boxer saying that "What you guys are throwing in here doesn't take care of everybody. You're only take care of a few constituents, and yet you're going to ruin the whole damn thing trying to do that. You're just trying to get a bill through that isn't going to work. Or if it does, it's only going to work for a few, not for everybody".

\section{MB: They'll say it's for everyone.}

RG: Yeah, you're saying its for everybody and we'll never get another one, because we've tried and tried and tried to get one. And we still got all these tunnels and people want to take the water from Sacramento Northern California watershed. You have no clue what you're going to do to that watershed when you take the water out? There is one dam that getting some favorable support and that's called the Site Dam up north, north of Folsom, up a little ways. It's a good sized one, it comes off, I think, the Sacramento. But they got it all supposedly figured out, that they're only taking during the high water, making sure that there's plenty of water for whatever fish there needs to have. The storage is big enough that it'll be able to take care of whatever it needs. They're not pushing for the tunnel aspect because this goes in. In other words, that's where the tunnel would come through, would connect. But everybody's seeing that, but with even the environmental groups are happy, to a degree, this is one that's trying to meet everybody's needs. Could be one that works, but here we can't even keep Millerton full, and we're not taking care of our upper watersheds, no money going to the meadows, or any of the watersheds, to thin the trees. Look at all the dead trees. I keep telling these people, that is not from bug and drought. Bug and drought is what killed them, but it's not what kiled them. What killed them is forest management practices. They were all growing too thick. Where are you thin? In Dinkey, in my meadows, I got one of my meadows up there in Bass Lake, just orange completely around it. Inside of it, I got 2 cedars that are dying. Ain't dead yet, but they're dying, and one top-the whole 10 acre meadow. Outside of it, dead thick - tree after tree after tree. But not where we thinned. So wherever I drive, wherever I see the forest thinned before, it looks good. Maybe one or two trees, that's it. Outside of that? They're all dead. It made it easy for the bugs in the drought, because they needed more water. But those that were thinned out, were able to get enough water stored. And those root systems store taht water. They're able to keep and pull up the water that they need to have other than that. Conifers have a 2 meter straw - they can reach down 2 meters, and if they pull up that water from 2 meters down, which is the depth of this counter [points], then plants and stuff can grab a meter down. And so, like in my meadows which I have restored all my native plants, they turn grey, they don;'t die, til the spring comes or winter comes, because they're still able to pull up, the trees that we do have there, they're able to keep up enough water...

MB: It seems like every article I read about the tree mortality, they talk about the drought and bug kill, but they barely touch on the over-suppression of fires and mismanagement.

RG: Everywhere I go I piss everybody off. I always got to tell them, it ain't about the beetle and the drought... And then you read like in yesterday's paper, oh, we're getting more rain, we need that rain, we've had 5 years of drought. Excuse me? We havent drought for 2, 3, we're in our 3rd good year. We left the drought 2, 3 years ago. And last year definitely had no drought problem. There's a residue of stuff that is still dying, that was already dying. It's kind of like I tell people, and people laugh at me, doing my analogy, but it's kind of like a dying man. A man's crawling across the desert, only got so much water, and manage to cut him a cactus flat, sips on a little drop or two of morning dew and keeps crawling. Then he comes to this spring and sticks his head in there and has a big drink and dies. Drank too much water, killed him! And these trees are that way, they've been fighting the drought for 4 or 5 years and now they've got plenty of water and now it's like "Shew!" Can't handle that! That wasn't our system, it's created a different system. The reason I say that is because a number of these trees, especially in my meadows, I've got on meadow, Meserve that you were on before, I've got about six different trees that died right in the meadow. It took them all summer, whereas the big trees, when they get hit, they're gone. These guys were grey, then they were blue-green, then they were starting to brown, then one side was brown, and then pretty soon - several months, 4 or 5 months - some of them still got a few green leaves on them. But they're dead. 
MB: Just a lack of water?

RG: yeah, well, too much water after having a lack of water. Noe they've got to much water, because I don't even see bug holes, don't see beetle holes, don't see anything. Sure, the beetle's there, ahs been, but you can't say it's the drought, it was drought in the sense that it was, they created themselves a system...let me show you something else, part of my research...

MB: OK

[01:04:48]

RG: I've been on Mariposa, I've got a whole thing on my research on climate change, I've been studying various plants that I gather, foods, what time they come up, and when to gather them-what is their actual harvest window. So throughout this whole drought, and my drought is from 1993. We're now in year 26 of drought—we've had 4 droughts in that time period: '93, 2002, 2007, 2010, OK? 4 droughts. And...er, '11 that was... during that time period, and each one of them only lasted 3 years, 4 years at the most, 4 th year is kind of a between year, then you switch over and you go again with water, then boom you get hit again. But that's what we've been in, but yet our harvest window has never changed. So if it's May 1 to August 1, that hasn't gone outside of that. Or if it's April 1 to July 1, nothing's gone outside of that. Inside of that, lots of fluxuation. When it's a good year, you can harvest 3 times. Not so good year, you can harvest early and late, or mid and late. Then it got to where there was a short window up front. This year what it did was, almost everyone of our plants had a pre-crop, so when I was burning with Jared, sawberries were out in April, so May we were trying them, they were no good. Had no taste, no seeds. Wasn't crunchy at all, no crunch. As the boys would say, "No crunch to these berries!". And then they died. June, all new berries came in, and when we gathered in July, you could see that pre-crop had gone down to little bitty red berry, all dried up, all shriveled up, in on the plant, but here was new nice fresh crop that you're gathering.

MB: What do you think is going on?

RG: Drought, resistance, and the plants had a plan, "This is how we're doing it. Oh! We still got water. Wait! We got to go back to our plan B, but wait a minute that used to be Plan A". Right? And then they were back to like "Oh, OK". So, let me see if I got it on here, do I got it on here? [pulls out phone]. So the tips of this water oak, is dead. And in May, April/May, the whole tree looked dead. This is July, the tips of the tree is still dead, but look at the trunks and look at the limbs, they're hairy, covered. And your leaves don't normally grow there. That's not where your leaves grow. You know? It's kind of like hair, if somebody turned hairy, "I got no hair on my face but look at my body!" Woah, what happened!

RG: You've probably never seen that before, huh?

RG: Nope. But yet the ends of the trees, that's a little one [showing photo on phone], big ones, little ones. Now this is, you have to go really big [zooming in on phone], you can see all new growth, these new leaves are really huge, and there are older leaves inside. This is the [???] berry, kind of an oak. So, it's doing the same thing. It's decided, "I still got water! Hey! Alright, I can make more leves. Oh I make good-sized leaves!" And this is July, again, late July. One week before I went to surgery, I went to my last gathering and I took these pictures.

MB: And where was this? 
RG: Mariposa. And when I drive all over, even in North Fork, I found trees like this_-just to see what they were doing.

MB: And it's just a response to the added water?

RG: Right, "Oh my God! What do you mean—-this is July, what do you mean I still got water? Oh, OK."

MB: I've heard that it's sort of cyclical, sort of like what you talked about: drought for 3 or 4 years...

RG: Yeah, these guys, these scientists, these new papers, "We're still in the drought!" It's like, oh, come on man. Another thing is that scientists all came out with climate change. I keep yelling at everybody. "Well we're in climate change!" Yea, we are, we are always in climate change. Climate change is a process. We are not permanently in climate change. In other words, we are not stuck just on that diamond [points to floor tile], or that block.We can go to all these black blocks, but time changes, it's always going to change. And that's what my study is. I'll send it to you. About how things change, it fluctuates, but we're not stuck in one spot. Climate change is something that our people all knew about. We'd even heard of global warming, heard of it [inaudible], but as an archaeologist have you ever studied drought?

MB: Well, I mean, climate does change, what is it? The medieval climatic anomaly?

RG: Arizona University has a great study on drought, and what their study was on the riverbeds and creeks, and shorelines, this is whAt they studied. Now, locally, other archeologists doing our digs have information on when, in a site, things have gone, people have gone absent, it's a timeline. Over here where I've been burning in Mariposa, we burned the sawberries, and the following year, before they sprouted, and they already had little sprouts, before they got thick, I started finding artifacts. Always found artifacts, but these are real artifacts. I have them and I recorded them. Pinto, 8,000 years old. 2 martices, 6-8,000 years old. Other artifacts, down the line. A lull, this is on the surface, so it's not total, a lull between 650 and 1650 . Archaeologically, and according to Arizona, there was a drought 650, 1000, 1100, 1250 to 1600, and then 1924. And then 1992. Those were the droughts. Archaeology, here in Tulare, we already knew about the drought between 1250 and 1600, but we didn't know about the 11,10, 6. So when they said it, it's like "Whew! I'Ive got a thousand years, 650-1650 it happened, but yet my site is 8,000 years old, or older. So, during that period, what happened? There wasn't"t enough people here? I may find evidence for 10,000 years but not as much evidence. The site I'm on right now, big enough for 600 people. 600 people. This is what Doug McKay_-I said 300, he said 600_it's 50 acres minimal,. We've got 3 bedrocks, one is 120, one's in the 80's, and the other's 54 and 60 holes, and then numerous small ones, medicine rock. Big, big, 20 acres with spots everywhere, just huge.

MB: That's a lot of people.

RG: Yea, and lots of water. But, again, I'm just looking and saying "OK, what happened to my artifacts here?" And then when you start and going, and then Arizona did their study on the San Joaquin and the Sacramento, right? And that's the two, s=those are their timelines of when drought took place.

MB: So what do you think was going on? People were going other places, or....

RG: You have to go where water is, and you also have to reduce your numbers. And that's what we're not doing. And that's what upsets me over the farmers and this water issue. The farmer still has the same allocation he did in the 1980s. But ion the 80's Fresno was 360,000, Clovis was 60,000. Now Clovis is 110,000, and Fresno is 660,000. 
MB: They ain't drinking less water, or using less water.

RG: Yea we have doubled in our urban. How much more water are we using? This last year was the first year for conservation, they're not doing it now.

MB: "Oh we'll do it for one year!"

RG: Yea, "We're god now". So, you know, people are not seeing that, that big picture and our numbers have to reduce or we better start maintaining here. We cannot keep the numbers coming like this. But that's what's just driving..."Oh we have to have another lake". No! That's not going to fix your problem. Our problem is too many. Send them over to Montana or Utah, or someplace, or we got to put a law in saying you can only have 2.5 babies [laughs] or whatever.

MB: Something's got to change. And like you said, the climate's always been changing, just look at the past, like you were talking about. It could be one of those rare instances where archaeology can actually maybe help.

RG: Could be. The other thing is that that Point Blue? conservancy came out with a great article a year ago or more, which substantiated the fact that the global warming, and how they're talking about ice sheets coming off in Antarctica and the ocean itself warming up, rising. Well, but on the other hand, when they went up and down, there's very little water coming from the creeks, and the creek water, no matter how small amounts are coming to the oceans, they're still cool. So more of it, they would be cooler, and that's what cools the ocean. and this is their point, too, and it's a really good one. And then you got people like Trump coming along " It;s ridiculous! They want the water to go to the ocean!" Exactly! Because, like you said, we're only speaking about ourselves right now. They're not thinking about in terms of 7 generations, 100, 120 years from now. The Forest is talking that way now, "Oh we got to be thinking about the next 10 years." Oh really? Now? Ok, then let's start thinking that way. It's one thing to talk the talk, it's another thing that you walk the talk, and you walk the walk. And they're not doing that. That Dinkey

Collaborative.... lot of talk. No walk. So that;'s why people are walking. Why the wilderness people have gone, the Davis people are gone, the Merced people show up once in a while, North Fork Mono Tribe's ready to walk. Sierra Legacy walks, others are slowly beginning to-well, we'll see what tomorrow's meeting looks like.

MB: Yea, I'm kind of curious about that.

RG: I may not go anymore after that, but I'll go. 